\title{
Uygulama imar planı tadilatlarında plan değişikliği ölçütlerine uygunluğun araştırılması
}

\author{
Investigation of compliance with plan amendment criteria in implementation zoning plan \\ amendments
}

Yaşar İNCEYOL ${ }^{* 1, a}$

${ }^{\text {I} A d ı y a m a n ~ U ̈ n i v e r s i t e s i, ~ T e k n i k ~ B i l i m l e r ~ M e s l e k ~ Y u ̈ k s e k ~ O k u l u, ~ I ̇ n s ̧ a a t ~ B o ̈ l u ̈ m u ̈, ~ 020040, ~ A d ı y a m a n ~}$

• Geliş tarihi / Received: $12.05 .2021 \quad$ Düzeltilerek geliş tarihi / Received in revised form: $20.09 .2021 \quad$ • Kabul tarihi / Accepted: 02.10 .2021

\section{$\ddot{O} z$}

Kırsala göre daha fazla nüfusun yaşadığı şehirlerde, insanların barınma, yol, dinlenme, eğitim ve sağlık gibi ortak yaşam alanları imar planları ile planlanır. Bu planlama mevcuttaki ihtiyaçlar ve gelecekteki durum dikkate alınarak yapılır. Hazırlanan imar planlarının uygulanabilirliği o kentte yaşayanların gerçek ihtiyaçlarının belirlenmesi ve kentin konumu ile örtüştürülerek sürdürülebilir bir kentsel yaşamın öngörülmesi ile doğrudan ilişkilidir. Bu süreçte ne kadar çaba gösterilirse gösterilsin imar planında bazı eksikliklerin olması kaçınılmazdır. Bu eksiklikler çoğunlukla, ortak kamusal alan ihtiyacının veya arazi sahiplerinin beklentilerinin karşılanamaması şeklindedir. İmar planı değişiklikleri, onaylı imar planının ihtiyaçları karşılamadığının objektif ölçütlerle belirlendiği "zorunlu durumlarda" ve "kamu yararı" gözetilerek yapılmalıdır. İmar planları hazırlanırken yol, park, okul, hastane gibi ortak kamusal alanlar için ilgili arazi sahiplerinin muvafakatleri alınmaz. Ancak mülkiyet hakkının bu derece kısıtlanması ve planı uygulayan idarenin gücünün artması, bu durumu dengeleyici karşı mekanizmaların gelişmesine neden olmuştur. İmar planı değişikliği de bu mekanizmalardan birisi haline gelmiştir. Bu çalışmada; yasal mevzuata göre imar planı değişiklik ölçütleri belirlenmiş, Türkiye'nin her biri farklı illerinden seçilen plan değişiklik örnekleri incelenerek, belirlenen ölçütlere uyma durumları araştırılmıştır. İncelenen örneklerde, plan değişikliğinde en önemli ölçüt olan "kamu yararı" kısmen gözetilmekle birlikte, daha çok "arazi sahiplerinin taleplerinin dikkate alındığı" ve "plan değiş̧iklik ölçütlerine uygunluğun tam olarak denetlenemediği" tespit edilmiştir.

Anahtar kelimeler: İmar planı, İmar planı değişikliği, Kamu yararı, Plan değişiklik ölçütleri

\begin{abstract}
In the cities wherein a larger population than rural areas are residing, common living spaces of people like housing, roads, recreation, education, and medical care places are all planned via zoning plans. This planning is plotted as per the current needs and future projections. Applicability of the zoning plans are directly associated with the identification of the residents' real needs in the city and anticipation of a sustainable urban life by fitting these needs with the location of the city. However, it is unavoidable to have some deficiencies in the zoning plan despite the utmost effort paid for the plan. These deficiencies are generally the dissatisfactions of either common needs of public space or land owners' expectations. Zoning plan amendments are supposed to be made in case of "obligatory situations" which are exhibited with objective criteria revealing that the current plan is unable to satisfy the needs and to be made with care of "public interest". While preparing zoning plans, the consents of landowners are not obtained for common public spaces like roads, parks, schools, and hospital. Nonetheless, such restrictions on freehold estate and the increase of the executing administration's power have also caused improvement of counterbalancing mechanisms. Zoning plan amendments have also become one of these mechanisms. In this study, zoning plan amendment criteria have been determined as per the legal regulations, the amendment samples -each of which selected from a different city of Turkey-have been examined and the compliance level of these amendments with the determined criteria has been analyzed. Following these examinations, it was found out that the demands of landowners have mainly been taken into account and the compliance of amendments with plan amendment criteria cannot be controlled implicitly while 'public interest' as the most important criteria of plan amendments has been partially satisfied.
\end{abstract}

Keywords: Zoning plan, Zoning plan amendments, Public interest, Plan amendment criteria

\footnotetext{
${ }^{*}$ Yaşar İNCEYOL; yinceyol@adiyaman.edu.tr; Tel: (0416) 22338 00; orcid.org/0000-0001-7455-2869
} 


\section{Giriş}

Bir kentin içerisinde barındırdığı nüfusun ihtiyaçları dikkate alınarak mekânsal biçiminin şehircilik ve planlama ilkelerine göre tasarlanması imar planları ile gerçekleştirilir. İmar planlarının uygulanabilirliği kentin gerçek verileri ve ihtiyaçları ile örtüşmesine bağlıdır. İmar planları kentsel işlevler arasında denge kurulmasını amaçladığı (Keleş ve Mengi, 2014) halde özünde bir takım ihtimallere ve öngörülere dayandığı için, çoğunlukla kesinlik içermez. Bazen planlamada kullanılacak verilerin doğru bir biçimde belirlenememesi, bazen de kentsel gelişme yönü ve büyüklüğü ile ilgili hatalı öngörülerde bulunulması, planlama hedefinden uzaklaşıı lmasına neden olur (Y1ldiz, 2014). Ayrica imar planları her türlü planlama ölçütüne uygun hazırlanmış olsalar da sorumlu kurumun bu planları uygulamada isteksiz/yetersiz kalması veya zorunlu nüfus hareketleri/göç vb. nedenler, planların revizyonunu gündeme getirebilir (Çiçek, 2016).

Zaman içerisinde planlanan alanların ihtiyaçlara yeterince cevap veremez hale gelmesi, kamu yararı veya kişisel mülkiyetle ilgili bazı hakların önemli oranda zarar görmesi durumunda, plan kararları ve arsa kullanım fonksiyonlarının yeniden düzenlenmesiyle ilgili plan değişiklikleri yapılabilir (Çolak ve Öngören, 2014). Literatürde plan değişikliği ile ilgili çoğunlukla birbiriyle örtüşen tespitler oldukça fazladır. Suher ve ark., (1985): Sesli ve Karadavut, (2009); imar planlarında öngörülemeyen gelişmelerin, mevzuata göre "plan değişikliği" olarak ortaya çıktığını belirtmişlerdir. Altın (2006) ise imar planı değişikliğini; onaylı imar planının bütünlüğüne zarar vermeden ulaşım sisteminde, kentsel donatıların fonksiyon, büyüklük ve yoğunluklarında yapılan değişiklikler olarak kabul etmiştir. İnceyol (2019); imar planı değişikliklerinin, plan yapımı esnasında öngörülemeyen veya sonradan ortaya çıkan teknik ve doğal ihtiyaçlar nedeniyle zorunlu olarak, kentsel yaşam kalitesine ve plan bütünlüğüne olumlu anlamda katkılar sağlayabileceğini vurgulamıştır. Bademli (1998), imar planı değişikliklerinde yalnızca teknik faktörlerin değil, sosyal, ekonomik, hukuki ve politik faktörlerin de önemli bir rol oynadığını belirlemiştir. Alfasi (2006) ise, imar planı değişikliklerinin kentsel mekânın değişimini yönetmede, giderek imar planlarının yerini almakta olduğunu tespit etmiştir.

İmar planı değişiklikleri; (1) kamusal ihtiyaçlar ve (2) parsel sahiplerinin mülkiyet hakkına bağlı değişiklikler olarak iki grupta toplanmıştır (Çolak ve Öngören, 2014). Birinci gruptakiler; konut alanlarının okul alanına çevrilmesi, yol ağının genişletilmesi ve kamu kurumlarının ihtiyaçları doğrultusunda talep edilen değişiklikleri kapsamaktadır. İkinci grupta ise; park veya yol ağı içinde bulunan bir parselin konut alanına dönüştürülmesi, emsal artışı, kat artışı ve ticaret alanına dönüştürme değişiklikleri, kaçak yapıların veya bazı yapılardaki kaçak katların yasal duruma dönüştürülmesi ile imar sınırları haricindeki arazilerin imarlı hale dönüştürülme talepleri yer almaktadır.

İmar planı değişiklikleri yapılış gerekçelerine göre analiz edilirse, söz konusu sebep ve ihtiyaçlardan ziyade mevcut koşulların ortaya çıkardığı gerekçelerle yapıldığ 1 ve bu değişikliklerin kentsel dokuya ve plan bütününe bazı olumsuz etkilerinin de olduğu görülmektedir (Yavuz ve Sertyeşilişık, 2019). Bu konuda Sesli ve Karadavut (2009); parsel bazlı imar planı değişikliklerinin küçük ve zararsız görüldüğü fakat "kamu yararı" dikkate alınmadan, günlük ve yerel-politik gerekçelerle yapılması durumunda kentsel mekâna ve kimliğe zarar verici etkilerine dikkat çekmektedir. Ersoy (1997) ise plan değişiklerinin kentsel yaşam standartlarını yükseltmekten çok plan bütünlügüüe olumsuz etki yapabileceğini belirtmektedir.

Genel olarak kabul gören teorik yaklaşıma göre, imar planı değişiklikleri ancak "zorunluluk" durumunda ve "kamu yararı" gözetilerek yapılmalıdır (Kilınç ve Türk, 2018). "Катu yararı" ise, kişilerin bir arada yaşayarak oluşturdukları topluluğun varlığını sürdürmesine ilişkin bir çıkardır ve kişilerin mülkiyet hakları üzerindeki yetkilerinin sinırlandırılmasını gerektirir. Çoğunluğun faydasının en üst düzeye çıkartılması ve sosyal adaletin sağlanması için, kişi çıarlarının sınırlandırılması "kamu yararı" nın temel ilkesidir (Tekeli, 1988).

Günümüzde imar planı değişikliklerinin büyük bir bölümü parsel ölçeğinde yapılmakta ve çok sık kullanılan araçlara dönüşmüş durumdadır. Kılınç ve Türk (2018) tarafindan yapılan bir çalışmada; İstanbul'da 2008-2017 y1lları arasında 10288 adet plan değişikliği talebinin yapıldığ ; bu taleplerden 6824'ünün (\%66) onaylandığını belirtmişlerdir. Bir şehrin mekânsal bileşenleri sokaklar/yollar, yolların çevrelediği yap1 adaları, parseller/arsalar ve arsa içine yapılan binaların oluşturduğu mekânsal bir dokudur (Ünlü, 2018). Kentin bileşenlerini oluşturan bu biçimsel yapı imar planı değişiklikleri ile parsel sahipleri, inşaatçılar, emlakçılar, mimarlar ve büyük ölçekli yatırım kuruluşları arasındaki ilişki ile ayrıcalıklı imar 
hakları kazanımıyla son şeklini almaktadır. Böylece kentsel planlama ilkelerinin dikkate alındığı bir süreçten, inşaat piyasası realitelerinin geçerli olduğu bir sürece girilmektedir.

Bazı durumlarda; imar planlarının kentsel mekânın biçimlendirmede yetersiz kalması, parsel sahiplerinin kendi sorunlarına çözümler üretmelerine neden olmuş ve bunun sonucu olarak da ortaya çıkan plan değişiklikleri bu süreçte etkin bir rol üstlenmiştir. Bu kapsamda "parsel bazlı" olarak yapılan ve önemsiz/küçük olarak görülen plan değişiklikleri bir araya getirildiğinde çoğunlukla yeni ve oldukça büyük bir kentsel doku oluşturacak seviyededir (Ünlü, 2007). Bununla birlikte imar planları yeni binaların üretim aracıdır. $\mathrm{Bu}$ nedenle imar planları yapılırken, kentsel yaşam alanları oluşturmaktan ziyade insanlar için ilgi çekici objeler olarak konumlandırılan binalar daha öncelikli hale gelmekte, bu yaklaşımdan dolayı da "kamu yararı" ndan çok "kişisel çıkarların" ön plana çıtığı bir kentsel biçimlendirme sürecine girilmesi kaçınılmaz hale gelmektedir (Ünlü, 2018).

$\mathrm{Bu}$ çalışmada; uygulama imar planlarındaki plan değişiklikleri incelenmiştir. Birinci aşamada yasal mevzuata göre "imar planı değişiklik ölçütleri" belirlenmiştir. İkinci aşamada Türkiye'nin her biri farklı illerinden seçilen plan değişiklik örnekleri, değişiklik öncesi ve sonrası durumuna göre ayrıntılı olarak analiz edilerek belirlenen "plan değişiklik ölçütleri" ne uyma durumları araştırılmıştır. Literatürde incelenen plan değişiklikleri daha çok bir kent veya bölgedeki plan değişikliğinin sayısı, türü, amacı vb. istatistiksel bulguları kapsamaktadır. İncelenen plan değiş̧ikliklerinde en önemli ölçüt olan "kamu yararı" kısmen gözetilmekle birlikte, daha çok arazi sahiplerinin taleplerinin dikkate alındığı, 2020 yılı sonrası çıkarılan mevzuata rağmen parsel ölçeğinde plan değişikliklerinin yapılmaya devam ettiği tespit edilmiştir. Ayrıca plan değişikliklerinin yasal değişiklik ölçütlerine uygunluğunu denetleme sorumluluğunun da tam olarak yerine getirilmediği görülmüştür.

\section{2. İmar planı değişlikleri, yasal çerçeve, kamu yararı ve bireysel çıkarlar}

İmar planlarının hazırlanma sürecinde statik ve durağan bir plan anlayışının öne çıkması, belediyelerin plan kararları üzerindeki etkilerinin sınırlı olması, planı hazırlayanların kentin imkânlarını, kısıtlarını ve özellikle bazı sosyal güç dengelerinin taleplerini plana yeterince yansıtmamaları, plan uygulamaya geçtikten sonra planı hazırlayanların süreç dışına itilmelerine, bu aşamadan sonra da yerel mülkiyet sahiplerinin taleplerinin devreye girmesiyle yerel idareler, yoğun plan değişikliği istemleriyle karşılaşmaktadırlar (Ersoy, 1997). Planlama hiçbir zaman matematiksel kesinlikte olamaz (Yildız, 2014). Ancak imar planları, plan hükümlerini ve yapılmış olan planlamayı tamamıyla devre dışı bırakacak şekilde bir esneklikte ve farklı grup veya bireylerden gelecek taleplere göre kolaylıkla değiştirilebilen birer politik belge olarak da görülmemelidir (Ersoy, 1997).

\subsection{Yasal çerçeve}

3194 sayıl1 İmar Kanunu'nun 8/b maddesine göre, belediye ve mücavir alan sınırlarındaki imar planlarını yapma-yaptırma yetkisi ilgili belediyelerde; belediye ile mücavir alanlar dışındaki bölgelerde ise valiliklerdedir. Ancak bu yetki yerel yönetimler dişında çeşitli merkezi kamu kurum ve kuruluşlarına da verilmiştir (Tiyek ve Ulusoy, 2020). Bu kurumlardan İmar Kanunu'nun 9. Maddesine göre Çevre ve Şehircilik Bakanlığı en üst düzeyde imar ve planlama yetkisine sahip kurum olarak tanımlanmaktadır. Ayrıca; Kültür ve Turizm Bakanlığı, Toplu Konut İdaresi Başkanlığı (TOKİ), Bilim Sanayi ve Teknoloji Bakanlığı'nın onayı ile Organize Sanayi Bölgeleri, Özelleştirme İdaresi Başkanlığı, İlbank, Güneydoğu Anadolu Projesi Bölge Kalkınma İdaresi Başkanlığı (GAP Idaresi) gibi kurumlar kendi yetki alanları kapsamında kendi özel kanunları doğrultusunda özel amaçlı planlama yetkisi ile yetkilendirilmişlerdir (Öngören, 2020; Naml1, 2017).

Türkiye'de yürürlükteki 3194 sayılı İmar Kanunu'nun 8. Maddesine göre; “nazım ve uygulama imar planları, ilgili belediyelerce yapılır veya yaptirllir ve belediye meclislerince onaylanarak yürürlüğe girerler". İmar planları yürürlüğe girdikten sonra uyulması zorunlu belgeler haline gelir ve yasal olarak herkesi bağlayıcı bir konuma gelir. Ancak ilgili yasaya göre kesinleşerek yürürlüğe girmiş imar planları üzerinde bazı "zorunlu durumlarda" plan değişiklikleri yapılabilir. "Ancak imar planı değişikliklerinde uygulanacak süreç, imar planlarının yapım ve onaylanma süreci ile aynı olmalidir (3194/Md. 8-9)".

Türkiye'de imar planı değişikliklerinin Mekânsal Planlar Yapım Yönetmeliği (2014) ile "bilimsel ve nesnel gerekçelerle" yapılabileceği ayrıntılı olarak düzenlenmiştir. Söz konusu yönetmeliğin 26/1 maddesi; "İmar plan değissikliğinin plan ana 
kararların, sürekliliğini, bütünlüğünü, sosyal ve teknik altyap dengesini bozmayacak nitelikte, kamu yararı amaçl, teknik ve nesnel gerekçelere dayandırılarak yapılabileceğini" hükme bağlamaktadır. Danıştay kararlarında ise, "imar planı değişikliklerinde; kişilerin mülkiyet hakları ile kamu yararı arasinda makul bir dengenin korunması gerektiği" vurgulanmaktadır (Altın, 2006).

Yakın zamanda 20 Şubat 2020 tarihinde yürürlüğe giren 7221 sayılı "Coğrafi Bilgi Sistemleri ile Bazı Kanunlarda Değişiklik Yapılması Hakkında Kanun" ile 3194 say1lı İmar Kanunu'na, "imar plan değişikliği ile meydana gelecek değer artışlarının kamuya aktarılması" na yönelik Ek Madde 8 eklenmiştir. Bu değişiklik ile;

1) "Parsel bazında; nüfusu, yapı yoğunluğunu, kat adedini, bina yüksekliğini arttıran imar planı değişiklikleri yapllamaz",

2) "Bin metrekareden az olmamak kaydryla oluşmuş adalarda; ada bazında nüfusu, yapr yoğunluğunu, kat adedini, bina yüksekliğini arttıran veya fonksiyon değişikliği getiren plan değişikliklerinde ihtiyaç duyulan kültürel tesis, sosyal ve teknik altyap kullanimları; adanin merkezine en fazla 500 metre yarıçapl alanda karşılanmak zorundadır",

3) "Taşınmaz maliklerinin tamamının talebi üzerine ada bazında yapılacak imar planı değişikliği sonucunda değerinde artışı olan arsanın artan değerinin tamamı değer artış payı olarak alınır",

hükümleri ile plan değişikliklerinin "ada bazlı" olacağı ve plan değişikliği sonucunda oluşacak "değer artı̧ıının kamuya aktarılacağ̀" amaçlanmıştır. 15.09.2020 tarihinde de Çevre ve Şehircilik Bakanlığı tarafından çıkarılan "İmar Planı Değişikliği ile Meydana Gelecek Değer Artış Payl Hakkında Yönetmelik" ile plan değişikliklerinde oluşacak değer artışının "değer artış payl" olarak kamuya aktarılması ile ilgili işlemler yürütülmektedir.

\section{2. İmar planı değişiklikleri işlem aşamaları}

İmar planı değişiklik teklifi dosyaları serbest şehir plancıları veya kamu kurumu adına yapılacaksa kurumda görevli şehir Plancıları tarafından hazırlanarak belediye meclisine sunulmaktadır. Ancak değişiklik yapılabilmesi için, öncelikle müellifin yeterlilik belgesine sahip olması gerekir. Belediye meclisi plan değişikliği dosyalarını yasal mevzuata göre değerlendirilerek teknik inceleme için imar komisyonuna havale etmektedir. İmar komisyonda incelenen dosyalar, gerekçeli raporları ile tekrar belediye meclisine sunularak meclis başkanı tarafından görüşmeye açılarak oylamaya sunulması sağlanır (Karaman, 2012). Uygulama İmar Planı değişiklikleri işlem aşamaları şekil 1'de gösterilmiştir.

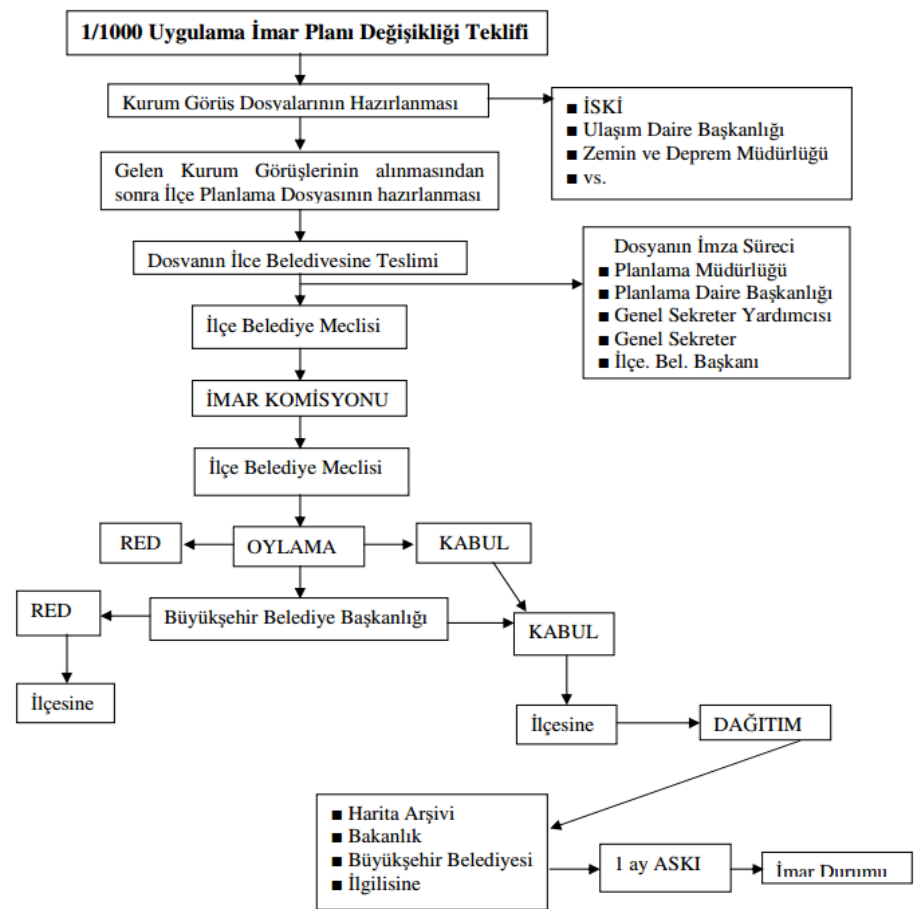

Şekil 1-a. Büyükşehir Belediyelerinde 1/1000 Ölçekli Uygulama İmar Planı Değişikliği İş akış Şeması (Altın, 2006) 


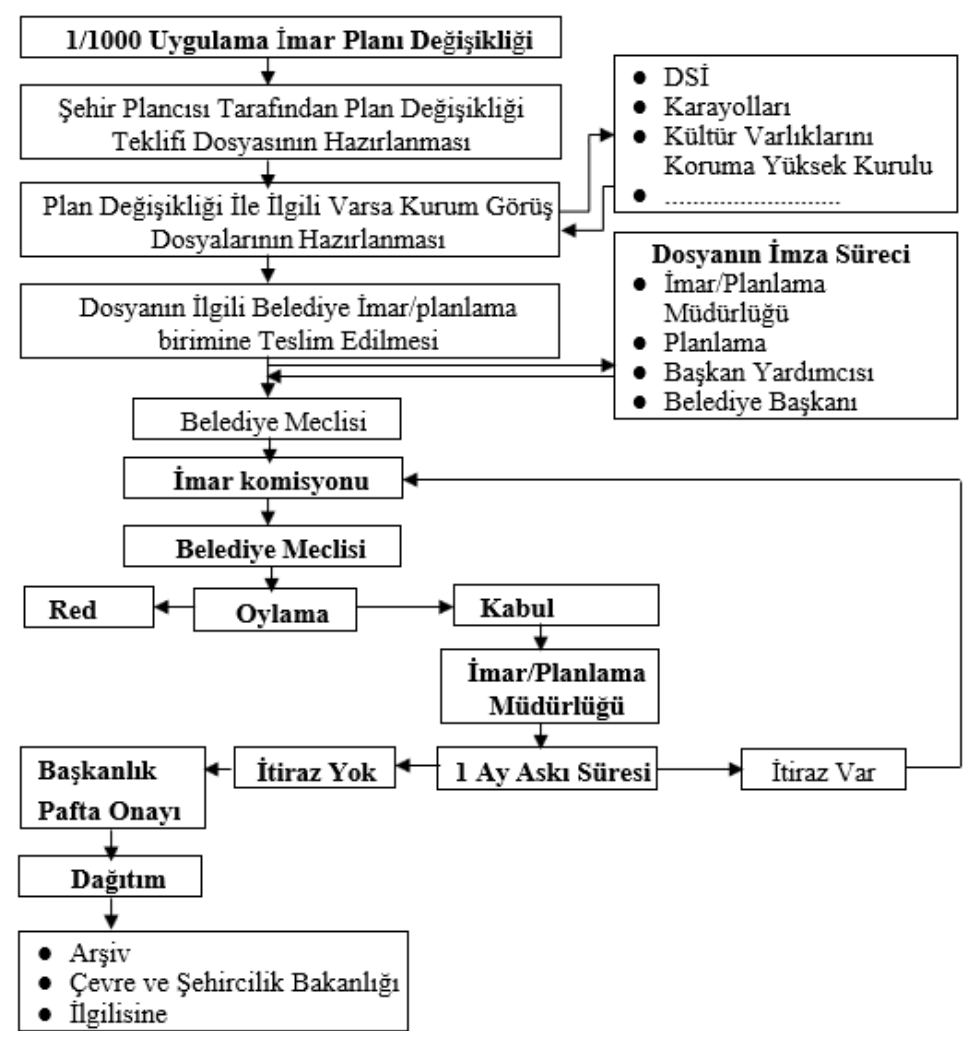

Şekil 1-b. Büyükşehir Dışındaki Belediyelerde 1/1000 Ölçekli Uygulama İmar Planı Değişikliği İş akış Şeması

\section{3. İmar planı değişiklik türleri ve zorunlu haller}

İmar planı değişiklik türleri Mekânsal Planlar Yapım Yönetmeliği (MPYY-2014) ile düzenlenmektedir: Yönetmelikte 4 farklı türde plan değişikliğinden söz edilmektedir. Bunlar; "(1) sosyal ve teknik altyapıya ilişkin plan değişiklikleri, (2) imar parsellerinde yoğunluğu artırmaya yönelik emsal değişiklikleri, (3) kullanım şeklinin değiştirilmesine yönelik plan değişiklikleri, (4) yolların genişletme daraltma ve güzergâhın değiştirilmesine ait değişiklikler" dir. "Imar planlarındaki sosyal ve teknik altyap alanlarının yerinin değiştirilmesi, küçültülmesi, kullanım fonksiyonunun değiştirilerek kaldırılmasına yönelik imar planı değişiklikleri zorunluluk olmadıkça yapılamaz" (MPYY-2014). $\mathrm{Bu}$ durumdaki zorunlu haller; "afetler, kestirilememiş demografik hareketler, ekonomik, sosyal ve teknolojik gelişmeler, üst ölçekli planlarda alınan yeni kararlar, maddi hatalar ve kesinleşmiş yargı kararları” dır (MPYY-2014).

\subsection{Imar planı değişikliklerinde kamu yararı ve bireysel çıkarlar}

Keleş (2008); imar planı değişikliklerinin bireysel çıkarları koruyucu, artırıcı nitelikte değil, kentin güzelleştirilmesi, işlevlerini görmesini kolaylaştırıcı, halkın esenlik, güvenlik ve rahatını artırıcı, yeşil alanlarını çoğaltan, trafik güvenliğini sağlayan, bu amaçlarla yollarını düzenleyen, genişleten ve plan bütünlügünü bozmaması gerektiğini belirtir. Eğer imar planı değişikliği için bir zorunluluk oluşmuşsa idari devamlılık ve kamu yararı ilkeleriyle desteklenmelidir (Tiyek ve Ulusoy, 2020). Bu bağlamda imar planı değişikliklerinde olması gereken bu kriterlerin tamamı "kamu yararını" tanımlamaktadır. "Kamu yararı" kavramının çok genel ve soyut düzeyde ifade edilen bir kavram olması nedeniyle imar planı değişikliklerindeki "kamu yararı" nın içeriği ve "değişikliği zorunlu kılan şartlar" dikkate alınarak belirlenmelidir (Ersoy, 1997). İmar planı değişikliklerinin kişisel çıkarlar için değil "kamu yararı" için yapılabileceği temel ilkedir. İmar planlarının kişisel çıkarları olumsuz yönde etkilemesi o kişilerin plan değişikliği taleplerini haklı çıkarmaz. İmar planlarının topluma sağlayacağı yararın kişilere sağlayacağı yararlardan daha fazla olması sağlanabilmiş ise, mülkiyet hakkını kısıtlasa bile, kamu yararının ağır bastığı kabul edilebilir. Yasal mevzuat ve Danıştay kararlarına rağmen, uygulamada çoğunlukla arazi sahiplerine bazı imar kazanımları sağlamak amacıyla imar planı değişikliklerinin yapıldığı da bilinmektedir. 
İmar planlama faaliyetlerinde belediyelerde yeterli uzman altyapisinin olmamasi ve belediye meclislerinin kapsamlı bir denetim fonksiyonu yerine getirememesi, imar planı değişikliklerini çoğunlukla parsel ölçeğinde inşaat alanının artırılması, yapı nizamı değişikliği ve mevcut fiili durumu koruyarak yasal hale getirmek gibi bireysel çıkar elde etmeye yönelik değişiklikler haline getirmiştir (Çiçek, 2016; Turgut, 2012). İmar planları her ne kadar "kamu yararı" ilkesi göz önüne alınarak adil bir şekilde hazırlansa bile nüfusun bir kesimi zarar görürken, başka bir kesim de bundan yararlanır (Bakır ve ark., 2018). Plandan zarar gören taraflar, mağduriyetlerini bir bask1 unsuru olarak kullanarak plan değişikliği önerilerini yoğunlaştırırlar. Plan değişiklik teklifleri belediyelerin imar komisyonlarında görüşülerek belediye meclisi tarafından oylanarak kabul edilirler. Belediye başkanı, meclis ve imar komisyonu üyeleri seçimle işbaşına geldikleri için seçmenleri yani parsel sahipleri tarafindan sürekli ve ağır bir baskı altındadır. Bu durum "plan değişiklik ölçütleri" nin yeterince dikkate alınmasını engellemektedir.

1985'de yürürlüğe giren 3194 Sayılı İmar Kanunu ile imar planı yapımı, uygulanması ve plan değişikliklerinin onaylanma yetkisi, merkezi yönetim süreç dışında bırakılarak belediyeler ile valiliklere devredilmiştir. $\mathrm{Bu}$ tarihten sonra bürokratik işlemlerin büyük ölçüde azalarak kolaylaştırılmış olması plan değişikliği taleplerinin, kabulünde ve değişiklik sayılarında oldukça ciddi bir artışa neden olmuştur (Ersoy, 1997). Turgut (2012) ve Çiçek (2016) tarafindan yapılan bir çalışmada plan değişikliği taleplerinin daha çok özel parsel sahiplerinden geldiği, buna karşılık kamu kuruluşları tarafindan teklif edilenlerin sayıca çok düşük olduğu, bazı büyükşehirlerde gerçekleşen plan değişikliği taleplerinin \%63 oranında "parsel bazlı" olduğu, $\% 41$ 'inin arazi sahiplerine büyük rantlar sağladığı, emsal artışı, fonksiyon değişikliği ve fiili durumu korumaya/yasallaştırmaya yönelik olduğu belirlenmiştir. Ayrıca 129 belediyenin yine arazi sahiplerine yol güzergahı değişikliği ile yarar sağladığı, geri kalan az sayıdaki plan değişikliğinin ise kamuya kaynak sağlama amacına yönelik olduğu, belediye hizmet alanı oluşturmak için yeşil alanların kullanıldığı, daha sonrasında ise bu belediye hizmet alanlarının planlama ilkeleriyle bağdaşmayan gerekçelerle ticaret alanlarına ve alışveriş merkezlerine dönüştürüldüğü belirlenmiştir. Yine İstanbul-Zeytinburnu ilçesi plan değişikliklerini inceleyen Demir (2009), 1995-2009 y1lları arasinda yapilan plan değişikliklerinin \%67'sinin kamu yararına, \%33'ünün ise "kamu yararl" na olmayan değişiklikler olduğunu tespit etmiştir. $\mathrm{Bu}$ araştırmada da görüldüğü gibi "kamu yararı" na olmayan plan değişiklikleri azımsanmayacak bir boyuttadır.

İmar planı değişikliklerinde yaşanan bütün bu olumsuzluklar, çarpık ve plansız kentleşmenin başlica sorunlarından birisi olarak kabul edilmiş ve yerel yönetimlerin imar süreçlerinde saydamlık ve hesap verebilirliğinin artırılması için birtakım düzenlemelere gidilmiştir. Bu kapsamda Çevre ve Şehircilik Bakanlığı'nca yayınlanan genelge ile plan değişikliklerine yerel yönetimlerce plan işlem numarası (PIN) verilmesi zorunluluğu getirilmiştir (Eminagaoğlu, 2018). Ayrıca Mekânsal Planlar Yapım Yönetmeliği (MPYY-2014) Madde 34'te "her tür ve ölçekteki planlar, plan notları, açılklama raporları ve ekleriyle birlikte alenidir. $B u$ aleniyeti sağlamak planı onaylayan idarenin görevidir. Ayrica idareler, internet sayfasinda sürekli yayımlamak suretiyle de planlara aleniyet sağlayabilir" denilmektedir. $\mathrm{Bu}$ aleniyetin sağlanması elbette ki plan değişiklikleri için de geçerlidir. Plan değişiklikleri "aleni" olmasına rağmen çoğunlukla yapanlar ve yaptıranlar tarafından takip edildiği, üçüncü kişiler tarafından şikâyet ve dava konusu edilme durumu da olmadığ için öylece kesinleşmektedir. Çok az sayıdaki dava ve şikâyet konusu edilen plan değişiklikleri ise çevreye duyarlı dernekler ve meslek odaları tarafindan takip edilmektedir. Ancak dava süreçlerinin uzun sürmesi nedeniyle alınan ruhsatlarla plan değişikliklerinin fiili duruma dönüşmesi, alınacak iptal kararlarını etkisiz kılmaktadır.

\subsection{Türkiye'de yapılan plan değişiklikleri ile ilgili} bazı sayısal göstergeler

Çevre ve Şehircilik Bakanlığı'nın tarafından yayınlanan Türkiye geneli plan istatistiklerine göre (https://e-plan.gov.tr/KesinlesenPlanListesi) 2014-2021 y1lları aras1 (2021 y1lı Ağustos ay1 dahil) Türkiye'de yapılan ve sisteme girilen plan nitelikleri tablo 1'de gösterilmiştir.

Tablo 1'deki verilere göre Türkiye'de son 7 yılda yapılan planların \%60.3'ü plan değişikliğidir. $\mathrm{Bu}$ plan değişikliklerinin 2014-2021 dönemini kapsayan y1llık ortalamas1 ise 7848 adettir. 2021 y1lı Türkiye İstatistik Kurumu (TÜİK) verilerine göre nüfusu 15462452 kişi olan İstanbul'da 20082017 yılları arasında 10288 adet plan değişikliği talebi yapılmış ve bu taleplerden 6824'ü (\%66) onaylanmıştır (Kilınç ve Türk, 2018). TÜİK verilerine göre nüfusu 3101833 kişi olan Bursa 
Büyükşehirde 2020 yılında yapılan ve itirazlar hariç onaylanan plan değişikliği sayısı 1099 adettir (TMMOB, 2020). Türkiye geneli yapılan yıllık plan değişiklik ortalaması ve örnek olarak verilen iki büyük şehirdeki yıllık plan değişikliği sayıları, kentlerin nüfusları da dikkate alındığında, oldukça yüksek değerlerdedir. $\mathrm{Bu}$ göstergeler plan değişiklerinin yüksek oranları hakkında yeterince bir fikir vermekte, ancak içerikleri ve "plan değişiklik ölçütleri" ne uyulup uyulmadığ 1 konusunda bir ayrıntı içermemektedir. Bu nedenle plan değişikliklerinin ayrıntılı olarak incelenerek "plan değişiklik ölçütleri" ne uygunlun araştırılmasına ve "bütüncül planlar" olarak hazırlanan imar planlarının neden bu kadar yüksek oranlarda (\%60 üzeri) değişikliğe tabi tutulduğu da irdelenmelidir. Yapılan bütün plan değişikliklerinin tek tek incelenmesi bilimsel bir makale kapsamını aşacağı için, bu çalışma kapsamında rastgele seçilen 5 faklı ildeki imar planı değişiklikleri incelenmiş ve "plan değişiklik ölçütleri" ne uyulup uyulmadığı araştırılmıştır. Sınırlı sayıdaki "plan değişiklikleri" üzerinden bunu yapmak riskli bir durum olmakla birlikte "içerik" hakkında bir fikir vermesi amacıyla yapılmıştır.

Tablo 1. Türkiye genelinde 2014-2021 y1lları aras1 yapılan planların nitelikleri

\begin{tabular}{lcc}
\hline Plan niteliği & Adet & Oran (\%) \\
\hline İlave plan & 1738 & 1.9 \\
İlave revizyon & 2358 & 2.6 \\
Mevzi plan & 2290 & 2.5 \\
Plan & 25754 & 28.4 \\
Revizyon plan & 3743 & 4.1 \\
Mevzi plan & 146 & 0.2 \\
Değişikliği & & \\
Plan değişikliği & 54790 & 60.3 \\
\hline Toplam & 90819 & 100 \\
\hline
\end{tabular}

\section{Materyal ve yöntem}

\subsection{Plan değişikliği saha örneklerinin seçimi}

$\mathrm{Bu}$ çalışmada kent ölçeğinde ve belli bir zaman aralığında yapılan plan değişikliklerinin tamamı üzerinden istatistiksel bir araştırma ve veri analizi yoluyla sonuçlar üretme yerine, somut ve az sayıdaki örnek plan değiş̧ikliği dosyaları, belirlenen kriterlere göre değişiklik öncesi ve sonrası durumu karşılaştırılarak ayrıntılı olarak analiz edilmiştir. Bu kapsamda Türkiye'deki bütün belediyeler tarafından onaylanarak kesinleşen plan değişikliklerinin yayınlandığı Çevre ve Şehircilik Bakanlığının ilgili internet adresinden (https://e-
plan.gov.tr/KesinlesenPlanListesi) alınan her biri farklı illere ait 5 adet plan değişikliğinin açılandığ örnek materyaller seçilmiştir.

\subsection{Yöntem}

"Mekânsal Planlar Yapım Yönetmeliği”" (MPYY 2014), ile "İmar Plan Değişikliği ile Meydana Gelecek Değer Artışlarının Kamuya Aktarılması" na yönelik Ek Madde 8 (3194 sayılı İmar Kanunu Ek Madde 8-2020) çerçevesinde "kamu yararı ve zorunluluk" durumu da dikkate alınarak, aşağıdaki "plan değişiklik ölçütleri” belirlenmiştir:

a) "Sosyal ve Teknik Altyaprya İlişkin Değişikliklerde; "Bir sosyal ve teknik altyapı alanının kaldirllabilmesi ancak, bu tesisin hizmet götürdüğü bölge içinde eşdeğer başka bir alanın ayrlmast suretiyle yapılabilir. Eşdeğer alanin ayrılmasında yüzölçümü ve konum özellikleri korunur" (Madde: 26/3-b).

b) "Parsel bazında; nüfusu, yapı yoğunluğunu, kat adedini, bina yüksekliğini arttıran imar planı değişiklikleri yapılamaz".

c) "1000 $\mathrm{m}^{2}$ 'den az olmamak koşuluyla ada bazında; nüfusu, yapı yoğunluğunu, kat adedini, bina yüksekliğini arttıran veya fonksiyon değişikliği getiren plan değişikliklerinde ihtiyaç duyulan kültürel tesis, sosyal ve teknik altyap kullanımlart; adanın merkezine en fazla 500 metre yarıçaplı alanda karşılanmak zorundadır".

d) "Kat adedinin artırilmasinin istenmesi durumunda; bir yolun iki tarafindaki karşıllıkl bina cepheleri arasindaki mesafe $K=[(Y 1+$ Y2) / 2] + 7,00 $m$ formülüne göre bulunacak asgari uzaklı̆̆ sağlamalıdır. Y1 ve Y2 değişiklik sonrast yolun her iki tarafindaki bina yüksekliklerini ifade eder".

Seçilen plan değişikliği örnekleri belirlenen bu "plan değişikliği ölçütlerine” göre incelenecektir.

\section{Bulgular ve tartışma}

\section{1. "I nolu plan değişikliği” incelemesi}

"1 nolu plan değişikliği” olarak 14.12.2020 tarihinde "Malatya ili Yeşilyurt ilçesi Çilesiz mahallesi 4427 ada 6, 7, 8 ve 9 no'lu parsellere ilişkin 1/1000 ölçekli uygulama imar planı değişikliği” (Plan raporu: https://eplan.gov.tr/Anasayfa/FileUpload?type $=5 \&$ pinId $=$ $340606 \&$ gorus $=$ False $\&$ fromAski $=$ True $\&$ dap $=$ Fals e) seçilmiştir. "1 nolu plan değişikliği”" öncesi durum: 4427 ada $6,7,8,9$ parseller yürürlükteki 1/1000 Ölçekli uygulama imar planında "Emsal= 
1.50, Yençok= 6 Kat yapılaşma koşulu ile “Ticaret-Konut Alanı", olarak planlıdır (Şekil 3a). Düzenleme alanı mülkiyeti kamuya ait (TOKİ ve Yerel belediye), 50 m'lik bulvar üzerinde, çarş1 merkezinde, arazi olarak çok değerli ve yaklaşık 40 dönümlük oldukça büyük bir bölgeyi kapsamaktadır (Şekil 2).

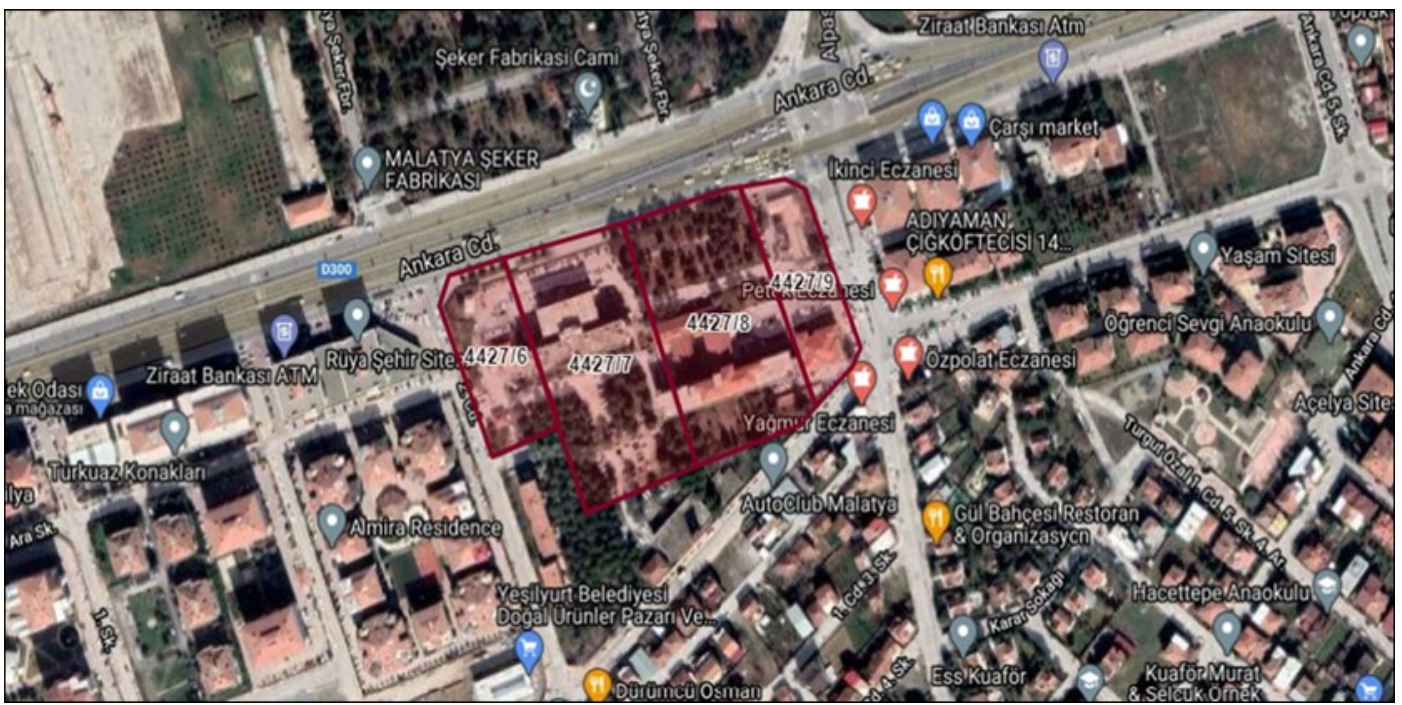

Şekil 2. 1 nolu plan düzenleme alanı uydu görünümü

"1 nolu plan değișikliği” sonrası durum: Yol kullanımlarında herhangi bir değișiklik yapılmadan, "Emsal= 0,02" ve "Yençok= 6,50" metre yapılaşma koşullarına sahip $31.408 \mathrm{~m}^{2}$ yüzölçümlü "Millet Bahçesi, Emsal= 1,50 ve

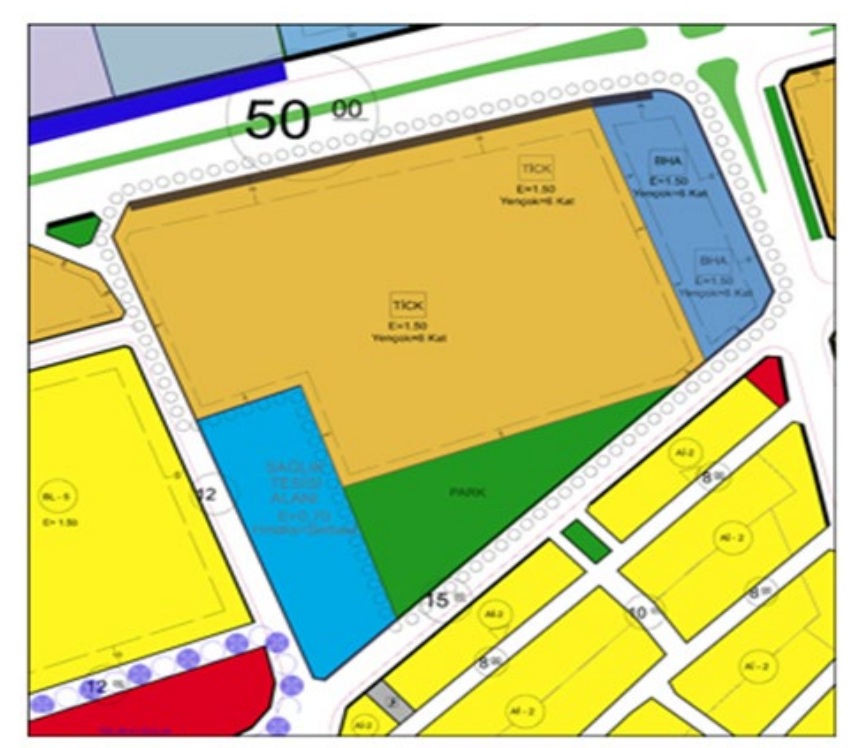

(a)
Yençok= 18,50 metre (6 kat) " yapılaşma koșullarına sahip $5.080 \mathrm{~m}^{2}$ yüzölçümlü "Belediye Hizmet Alanı" ve $4.375 \mathrm{~m}^{2}$ yüzölçümlü “Park Alanı” olarak yeniden düzenlenmiştir (Şekil 3-b).

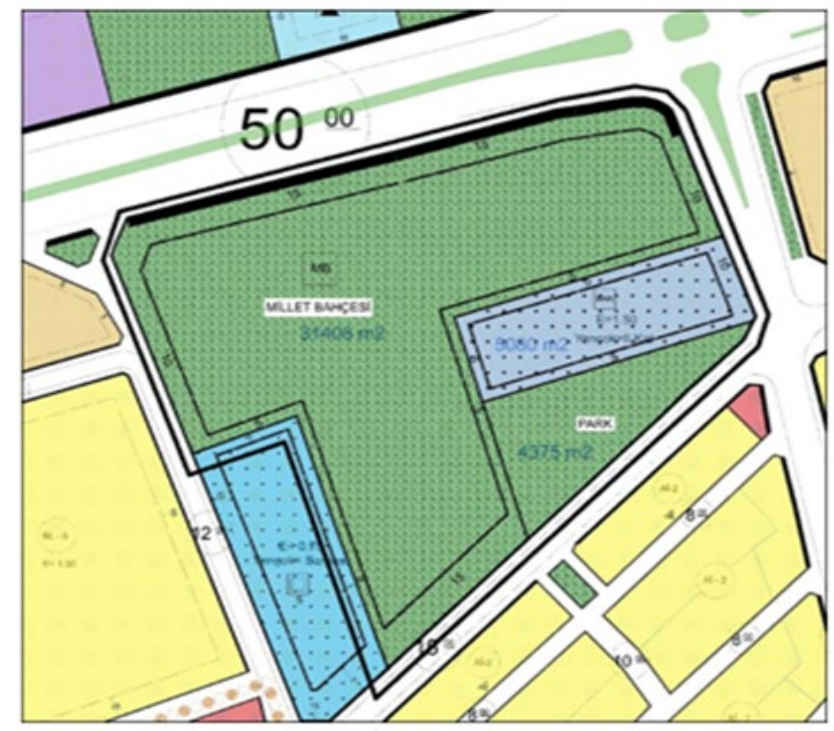

(b)

Şekil 3. 1 nolu plan düzenleme alanı plan değişikliği öncesi (a) ve sonrası (b) durum

"1 nolu plan değişikliği” için inceleme bulguları: Şekil 2 ve şekil 3’te görüldüğü üzere düzenleme alanının çevresi yoğun olarak "ticaret - konut alanları”, siteleşmiş apartman yapıları ve 50 metrelik karayolu kenarı ticari yapıların bulunduğu bir bölgedir. Mevcut imar planında $30.506 \mathrm{~m}^{2}$ 'lik büyük bir kısmı "Ticaret-Konut Alanı", olarak planlı durumda iken; söz konusu alanın kent ölçeğinde yeni bir sosyal yaşam alanı haline getirilmesi ve bölge halkının kullanımına daha modern ve büyük bir yeşil alan kazandırılması amaçlanmıştır. Kent merkezinde ve $40.864 \mathrm{~m}^{2}$ 'lik bu alanın ilgili kurumlara sağlayacağ büyük ticari getirisinden vazgeçilerek, bölge 
insanının sosyal yaşam kalitesinin artması, daha fazla yeşil alan ve sosyal donatı alanı ihtiyacının karşılanması için “kamu yararı" doğrultusunda yeniden işlevlendirilerek "Millet Bahçesi, "Belediye Hizmet Alanı ve Park Alanı" olarak yeniden düzenlenmiştir. Yapılan plan değişikliğinde "emsal artışı" ve arazinin sahibi olan kurumların herhangi bir maddi kazanımı söz konusu değildir. Plan değişikliği “ada bazlı” dır.

\section{2. "2 nolu plan değişikliği” incelemesi}

"2 nolu plan değişikliği” olarak 21.06.2020 tarihinde yapılan "Bursa Illi, Nilüfer İlçesi, Ataevler Mahallesi 1/1000 ölçekli FethiyeIhsaniye 1312 Ada 3 Parsel Imar Planı Değişikliği”" (Plan Raporu: https://eplan.gov.tr/Anasayfa/FileUpload?type $=5 \&$ pinId $=$ $317957 \&$ gorus $=$ False $\&$ fromAski $=$ True $\&$ dap $=$ Fals e21.06.2020) seçilmiştir.

“2 nolu plan değisikliği” öncesi durum: 1312 ada 3 parsel yürürlükteki 1/1000 Ölçekli uygulama imar planında "Emsal=1.25, Yençok $=15.5 \mathrm{~m} \mathrm{(5}$ Kat) yapılaşma koşulu ile konut alanı", olarak planlıdır (Şekil 4 ve Şekil 5-a). Düzenleme alanı özel mülkiyete ait olup, çevresi 10 ve 15 metrelik yollarla çevrili, konut - site alanları bölgesinde,

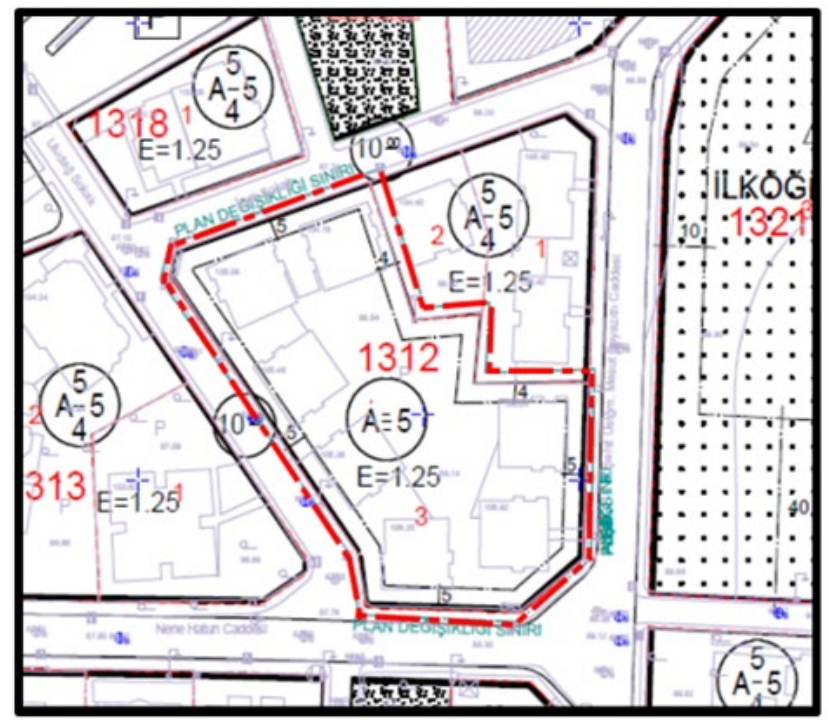

(a) konumsal olarak oldukça değerli ve 4921,00 $\mathrm{m}^{2}$ 'lik (Şekil 4) bir arsadır.

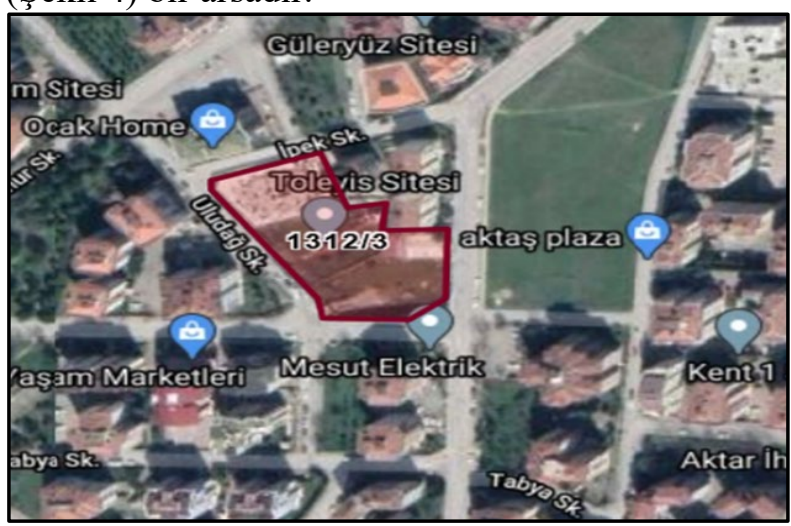

Şekil 4. 2 nolu plan düzenleme alanı uydu görünümü

“2 nolu plan değisikliğị” sonrası durum: Yapılan plan değişikliği ile emsal değeri arttırılarak "Emsal= 1.75, yapı kat adedi Yençok= 24.5 metre (8 kat), yapulaşma fonksiyonu konut alanindan TiCK (Ticaret + Konut)" alanına dönüştürülmüştür. Yap1 çekme mesafeleri değiștirilmemiștir. Artan inşaat alanının tamamının ticaret amaçlı kullanılacağı belirtilerek, meydana gelecek nüfus artışı karşıllı̆ı $606,33 \mathrm{~m}^{2}$ donatı alanı, parselin doğusunda park alanı olarak ayrılmıştır (Şekil 5-b).

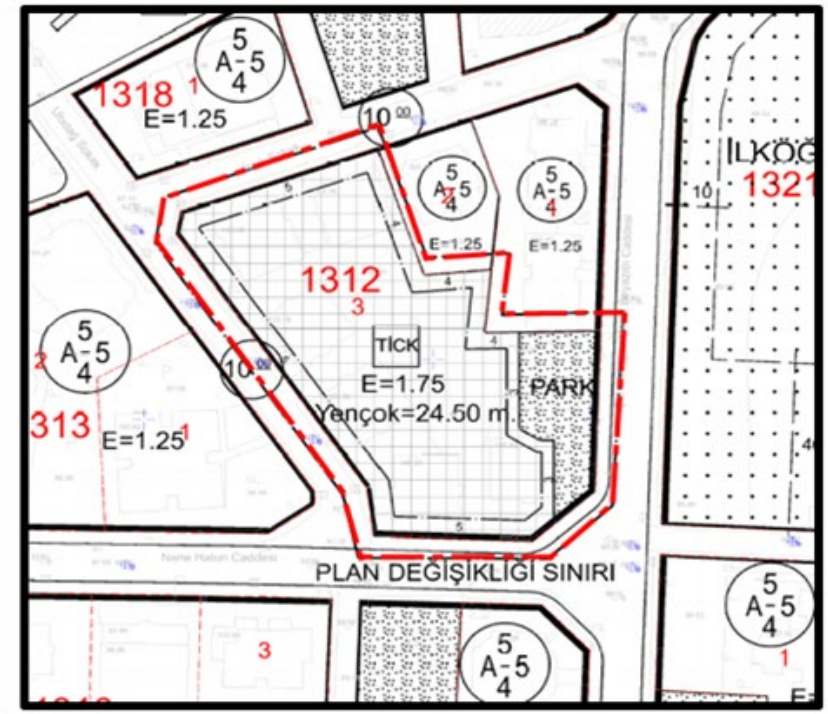

(b)

Şekil 5. 2 nolu plan düzenleme alanı plan değişikliği öncesi (a) ve sonrası durum (b)

\section{“2 nolu plan değisikliğị" için inceleme bulguları:} Plan açıklama raporunda söz konusu parsel için “yapı emsalinin 1.25'den Emsal=1.75” e, “yapt kat adedinin 5 kattan 8 kat (Yençok=24.5 m)" a çıkarılmasıyla ilgili plan değişikliğinin 2017 yılında yapıldığı, ancak bu plan değişikliğinin aynı y1l “mahkeme karariyla iptal" edildiği belirtilmektedir. Mahkemenin ana iptal gerekçesi "sosyal donat dengesinin olumsuz yönde bozulmast, "Emsal” e ilavenin maksimum 0,50'yi geçmeyecek şekilde düzenlenmesi, gerekli altyapt analizlerinin yapılmast, teknik ve donatı alanlarının ayrılması, ada bazında çözümleme yapılması" olarak vurgulanmıştır. 
2020 yılında yapılan plan değişikliğinde mahkeme kararında belirtilen iptal gerekçelerine kısmen uyularak yapılan plan değişikliği ile emsal değeri 0.5 arttırlarak “Emsal $=1.75$ ” $e$, Yapı kat adedi 3 kat arttırılarak 5 kattan 8 kata (Yençok $=24.5$ metre), yapılaşma fonksiyonu "konut alanından TiCK (Ticaret + Konut)” alanına dönüştürülmüştür. Uygulama imar planındaki emsal değerinden (E:1,25) gelen toplam inşaat alan1 $6151,25 \mathrm{~m}^{2}$ 'den $8611,75 \mathrm{~m}^{2}$ 'ye çıkarılarak, "toplamda 2460,50 $\mathrm{m}^{2}$ 'lik inşaat alant artışı (\%40)" meydana gelmiştir. Plan notlarına göre 0,50 emsal artışının tamamına karşılık gelen $2460.50 \mathrm{~m}^{2}$ 'lik alan, "ticari amaçll" kullanılacaktır. Mahkeme kararında bu artışın "ticari amaçlı olarak kullanılacağı" ile ilgili bir hüküm olmadığ 1 halde böyle bir karar alınmış ve bu artışla arazi sahiplerine \%40 'lık ticari amaçlı inşaat alanı kazandırılmıştır. $\mathrm{Bu}$ artışın değeri ayrı bir değerleme konusu olmakla birlikte önemli oranda bir artış olduğu görülmektedir. Mahkeme kararında istenen "gerekli altyapt analizlerinin yapılması" da dikkate alınmamıştır. Örneğin yoldan çekme 5 metre olarak değiştirilmediğinden 1312 nolu adada yapılacak bir binanın kuzey, güney ve batısında bulunan adalardaki binalarla arasında olması gereken asgari mesafe " $K=[(Y 1+Y 2) / 2]+7,00 m=27$ $m$ ” olması gerekirken plan değişikliği sonrasında hala $20 \mathrm{~m}$ olarak kalmıştır. Mahkeme kararında plan değişikliğinin "ada bazında" yapılması istendiği halde, "parsel bazlı" yapılmıştır. Plan değişikliği yapılan 1312 nolu ada içerisinde, değişiklik yapılan 3 nolu parselin doğusunda halen 5 katll, "emsal=1.25" olan ve yaklaşık adanın 1/3 'ünü kapsayan 1312/1 ve 1312/2 nolu 2 adet parsel daha mevcuttur. Bu durum değişikliğin “ada bazllı" olmadığını göstermektedir. Ayrıca 1312 nolu adada yapılan söz konusu emsal ve kat artışları komşu adalar ve hatta aynı ada içindeki 1312/1 ve 1312/2 nolu parseller için de emsal teşkil edecek niteliktedir. Burada açıklanan inceleme bulgularına göre bu plan değişikliğinde herhangi bir "kamu yararı" tespit edilememiştir. Mahkeme kararında yapılması istenilen değişiklikler bir "zorunluluk" oluştursa da kararda istenilenlerin dışına çıkılması "zorunluk" olarak değerlendirilemez.

\section{3. "3 nolu plan değişikliği " incelemesi}

"3 nolu plan değişikliği” 03.11.2020 'de yapılan Şanlıurfa ili Karaköprü ilçesi Seyrantepe mahallesi 282 Ada; 2, 4, 5, 6, 7, 8, 9, 10, 11, 12, parsellere ait 1/1000 ölçekli imar planı değişikliği (Plan raporu: https://e-

plan.gov.tr/Anasayfa/FileUpload?type $=5 \&$ pinId $=$ $336604 \&$ gorus $=$ False $\&$ fromAski $=$ True $\&$ dap $=$ Fals e) seçilmiştir. "3 nolu plan değisiikliği" öncesi durum: Planlama alanı yürürlükteki uygulama imar planında "E:1.50 ve Yençok $=45.50 \mathrm{~m}(15$ kat) " yapılaşma koşullarına sahip "Konut Alanı" olarak planlı, yaklaşık 35 dönümlük bir sahayı kapsamakta ve özel mülkiyete (Şekil 6) ait bulunmaktadır.

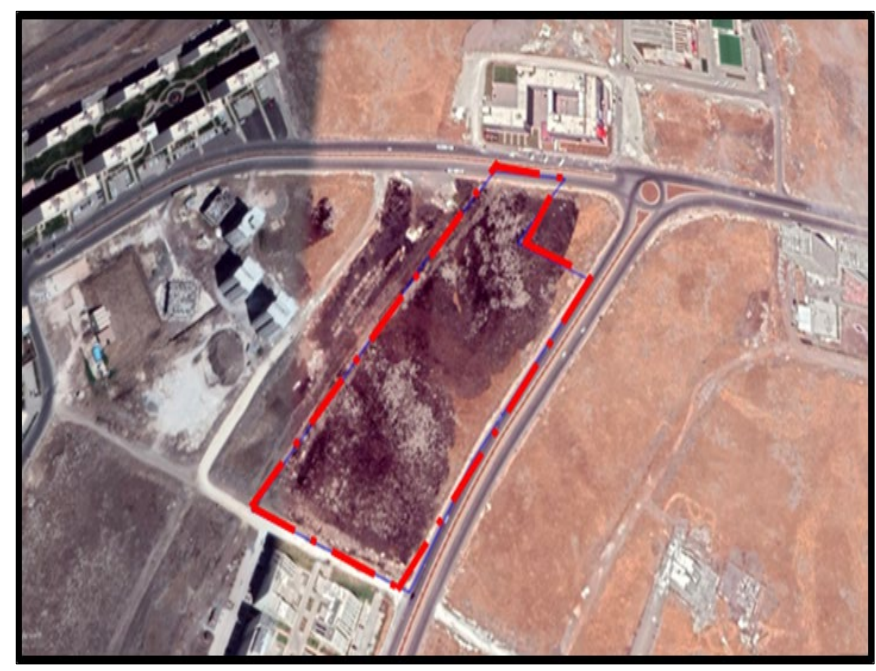

Şekil 6. 3 nolu plan düzenleme alanı uydu görünümü

“3 nolu plan değișikliğ̣i” sonrası durum: Şekil 7'deki düzenleme alanı incelendiğinde, plan değişikliği öncesi (a) ve sonrası durum (b) arasında hiçbir değişiklik görülmemektedir. Ancak plan açıklama raporunda "yapılan plan değişikliği ile yapılaş̧ma koşullarında değiş̧iklik yapılmadan plan notlarında düzenleme yapılmuștır" denilmektedir. Plan notlarında "konut alanlarında zemin katta 6.5 m yüksekliğinde asma katl ticaret alanı veya toplam inşaat alanının \%15 'ini 
geçmemek şartıyla băğımsız ticaret yapılabilir. Asma kat emsal dışı tutulacaktır" notu ile

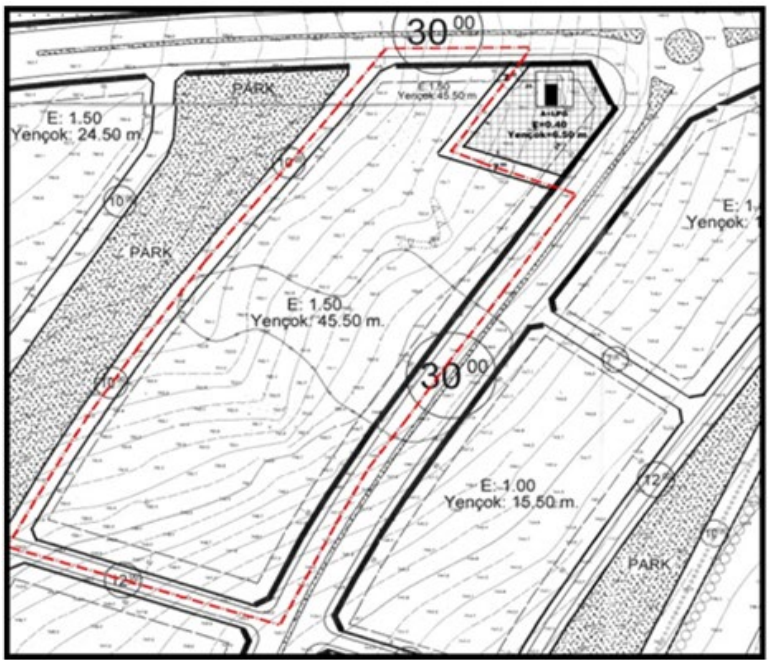

(a) düzenleme alanı "konut + ticaret" alanına dönüştürülmüştür.

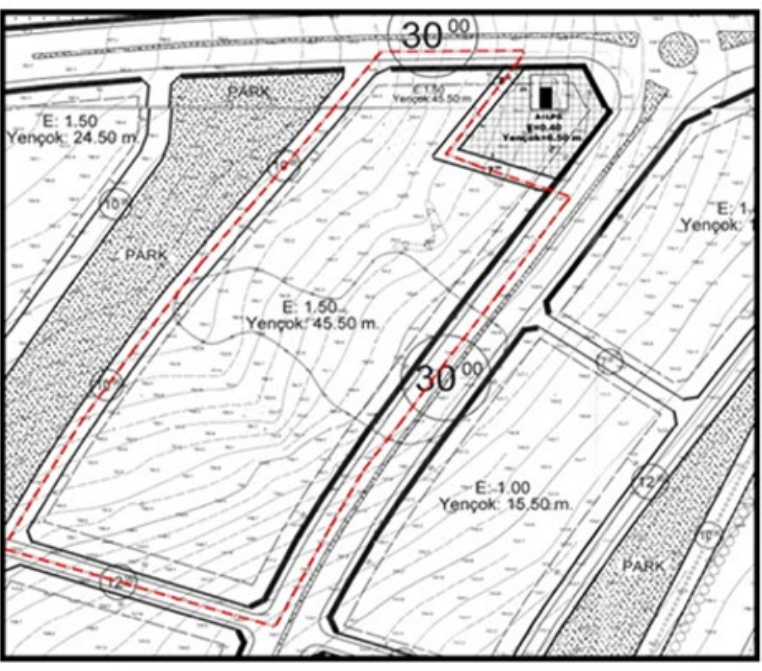

(b)

Şekil 7. 3 nolu plan düzenleme alanı plan değişikliği öncesi (a) ve sonrası durum (b)

"3 nolu plan değisikliğị" için inceleme bulguları: $\mathrm{Bu}$ plan değişikliğinde farklı bir yöntem izlenmiştir. Yapılan plan notu değişikliği ile “konut alanı" olarak planlanmış olan ada, "Konut + Ticaret” alanına dönüştürülmüş ancak öneri planda şekilsel olarak gösterilmemiştir. $\mathrm{Bu}$ değişiklik ile arazi sahiplerine $\mathbf{7 8 7 5} \mathbf{~ m}^{2}$ "ticaret alanı" kazandırılmıştır. Bu alanın, ada bazlı uygulamada "\%10 daha artabileceği”" de plan notlarında belirtilmiştir. Plan değişikliği yapılan 282 nolu adanın batısında 30 metrelik yola cepheli iki adet adanın yapılaşma koşulları "Emsal:1, Yençok=15.5 m (5 kat)" şeklindedir. Bu yapılaşma koşulları buradaki arazi sahipleri tarafından yeterli görülmeyecek ve bu adalar için, hatta $30 \mathrm{~m}$ yola cepheli aynı yapılaşma koşullarına sahip bütün adalar için de, plan değişikliği taleplerini tetikleyecektir. Aynı koşullarda yapılacak bu değişiklikler sonucunda ise $\mathbf{3 0}$ m'lik yolun her iki tarafinda yapılacak binalar arasında olması gereken asgari " $K$ mesafesi, $K=[(45.5+45.5)$ / $2]+7,00 m=52.5 m$ " olması gerekirken plan değişikliği sonrasında $50 \mathrm{~m}$ olarak kalmış olacaktır. Burada açıklanan inceleme bulgularına göre bu plan değişikliğinde herhangi bir "kamu yararı" veya “zorunluluk" tespit edilememiştir.

\section{4. "4 nolu plan değişikliği” incelemesi}

"4 nolu plan değişikliği” olarak 11.03.2021 tarihinde yapılan Bayburt ili Merkez ilçesi Şingah Mahallesi $223 \quad$ ada $72,73,74,75,76,77,78,79,80,81,82,83,87,88,89,90$, 91 92,93,94,95,96,97, 98 parseller ve 973 Ada 1 Parsel'e ait 1/1000 ölçekli uygulama imar planı değişikliği (Plan açıklama raporu: https://eplan.gov.tr/Anasayfa/FileUpload?type $=5 \&$ pinId $=$ $350454 \&$ gorus $=$ False $\&$ fromAski $=$ True $\&$ dap $=$ Fals e) seçilmiştir.

\section{“4 nolu plan değisikliğị" öncesi durum:} Planlama alanı 223 ve 973 nolu adaları kapsamaktadır. 223 nolu adadaki 24 adet özel mülkiyete ait parselin toplam alanı $11.392,53 \mathrm{~m}^{2}$, 973 nolu adadaki 1 adet özel mülkiyet parselinin alanı ise $4.045,90 \mathrm{~m}^{2}$ 'dir (Şekil 8). Yürürlükteki uygulama imar planına göre 223 nolu ada yapılaşma koşulları "Ayrık Nizam 3 Kat, TAKS 0.25, KAKS 0.75”, niteliği “Gelişme Konut Alanı” kapsamındadır. 973 Ada 1 Parsel ise "Cami" alanı (Şekil 9-a) kapsamındadır.

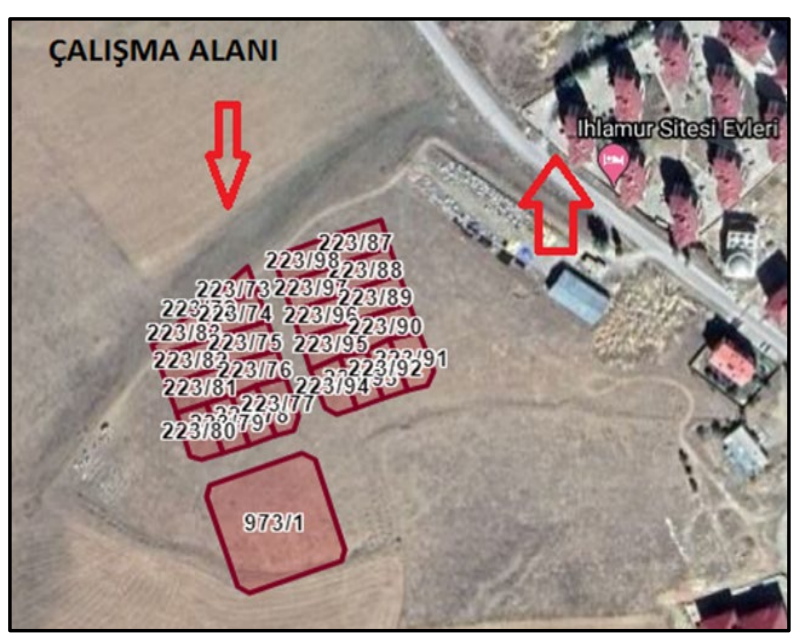

Şekil 8. 4 nolu plan düzenleme alanı uydu görünümü 
“4 nolu plan değisikliği”" sonrası durum: Şekil 9$\mathrm{b}$ 'deki düzenleme alanı incelendiğinde, 223 nolu ada, kuzeyindeki mülkiyet sınırından geçen ve 72 , 73,98 ve 87 nolu parsellere isabet eden 10 metrelik bir imar yolu tanımlanarak bölünmüş, yapılaşma koşulları “emsal: 0.75'den Emsal:1.80, kat

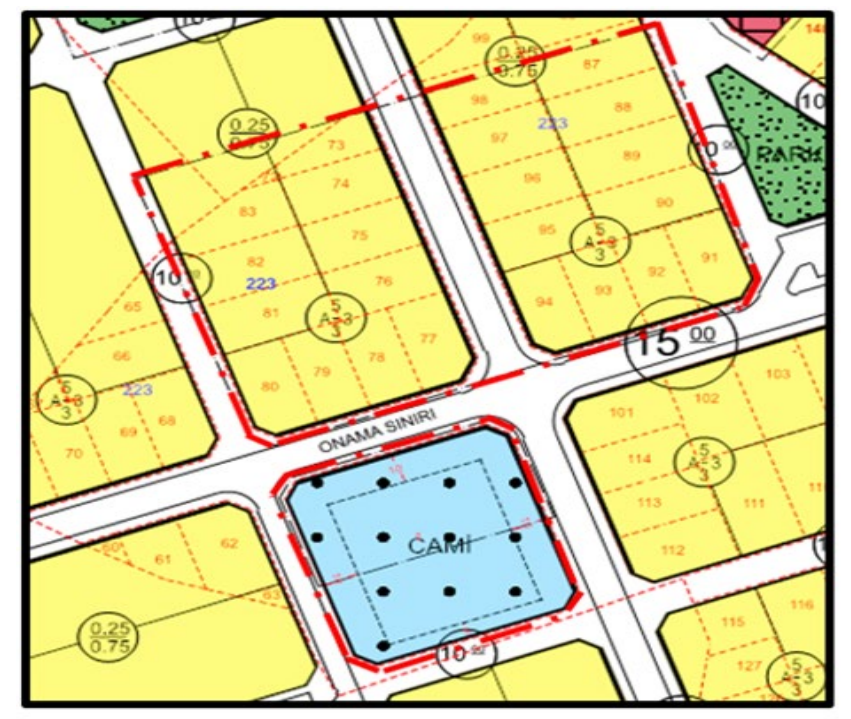

(a) yüksekliği 3 kattan 6 kata (Yençok=18.50 m)”, olacak şekilde değiştirilmiştir. 973 nolu adada ise, adanın niteliğinin yarıs1 "Belediye Hizmet Alanı", diğer yarısı "Cami” olarak değiştirilmiştir.

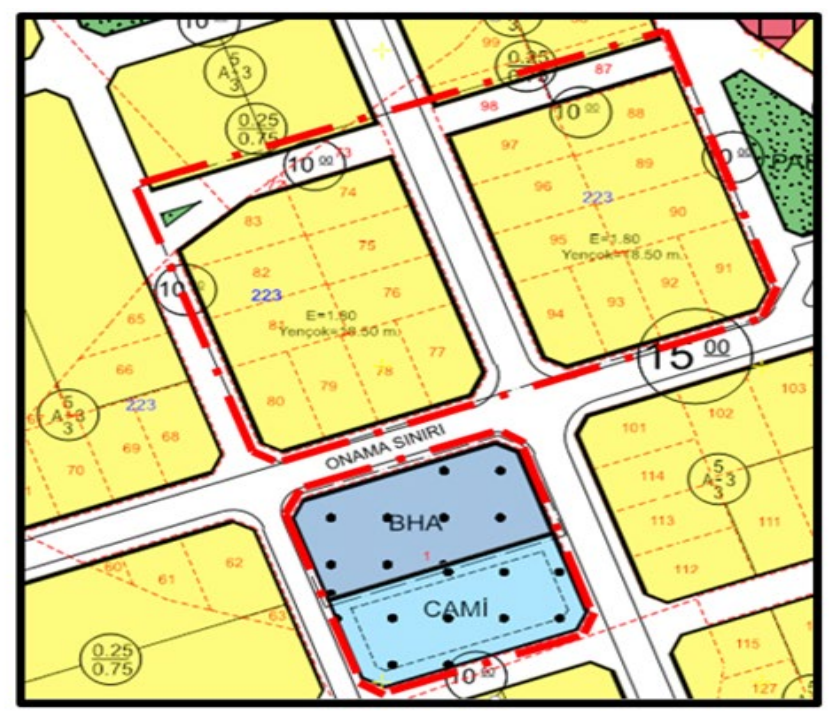

(b)

Şekil 9. 4 nolu plan düzenleme alanı plan değişikliği öncesi (a) ve sonrası durum (b)

“4 nolu plan değisikliğị" icin inceleme bulguları: Plan açıklama raporunda yapılan değişikliğin “03.02.2021/91 sayll meclis kararına istinaden" yapıldığ 1 belirtilmiştir. Yürürlüğe girmiş imar planları üzerinde yapılacak değişiklikler bölüm 2.1'deki yasal çerçeve ve detayları yine bölüm 2.2'de açıklanan işlem sırasına göre, önce "haklı bir gerekçeye dayandırılarak" plan tadilatının hazırlanmasını, daha sonra "mecliste görüşülerek karara bağlanmasını" gerektirmektedir. $\mathrm{Bu}$ değişiklikte önce meclis kararı alınmış daha sonra plan değişikliği yapılmıştır. 223 nolu ada için yapılan emsal artışı \%105, kat artışı \%100'dür. Bu artışta arazi sahiplerinin \%100'den daha fazla toplam inşaat alanı kazanımları söz konusu iken, herhangi bir "kamu yararı" veya bu değişikliği gerektirecek bir "zorunluluk" söz konusu değildir. Ayrıca bu değişiklik, düzenleme öncesi mevcut adanın tamamını değil, düzenleme sonrası mülkiyet sinırlarına göre oluşturulan yeni adaları kapsamaktadır. Yapılan plan değişikliğinde "emsal artışına bağlı olarak gerçekleşen nüfus artışına hizmet vermek üzere doğan yeşil alan ihtiyacı, kendi parseli içerisinden sağlanacaktır" denmekte, ancak yeni düzenlemede (şekil 8-b) herhangi bir yeşil alan görülmemektedir. Yapılan düzenleme sonucunda; adanın güneyindeki 15 m'lik yolun her iki tarafinda yapılacak binalar arasında olması gereken asgari “ $K$ mesafesi” sağlanırken, adanın batısındaki 10 m'lik yol için
" $K=[(18.5+9.5) / 2]+7,00 m=21 \mathrm{~m}$ " olmas 1 gerekirken, plan değişikliği sonrasında $20 \mathrm{~m}$ olarak kalmış olacaktır. Ayrıca şekil 8-b'de görüldüğü gibi bu plan değişikliğinin yapıldığı düzenleme sahasının etrafındaki diğer adalar "emsal: 0.75, kat yüksekliği: $3 \mathbf{m}$ ” yapılaşma koşullarına sahiptir. $\mathrm{Bu}$ plan değişikliği ile söz konusu adalar için de “Emsal: 1.80, kat yüksekliği: 6 m” talebi ile aynı emsal ve kat artışı için plan değişikliği yolu açılmış olacaktır. $\mathrm{Bu}$ adalarda da aynı plan değişikliklerinin yapılması durumunda ise " $\boldsymbol{K}$ mesafesi” nin sağlanması zaten mümkün olamayacaktır. Burada açıklanan inceleme bulgularına göre bu plan değişikliğinde herhangi bir "kamu yararl" veya "zorunluluk" tespit edilememiştir.

\section{5. "5 nolu plan değişikliği " incelemesi}

"5 nolu plan değişikliği”" olarak 03.03.2021 tarihinde yapılan Gümüşhane İli, Merkez İlçesi, Hasanbey Mahallesi 23 Ada, 2, 7, ve 10 nolu parsellere ait 1/1000 ölçekli imar planı değişikliği (Plan raporu: https://eplan.gov.tr/Anasayfa/FileUpload?type $=5 \&$ pinId $=$ $349291 \&$ gorus $=$ False $\&$ fromAski $=$ True $\&$ dap $=$ Fals e) seçilmiştir.

"5 nolu plan değişikliğì" öncesi durum: Planlama alanı 23 nolu ada ve 2-7-10 numaralı parselleri kapsamaktadır. Adı geçen parseller özel 
mülkiyete ait olup yüzölçümleriyle ilgili plan açıklama raporunda herhangi bir bilgi verilmemiş̧ir. Tapu ve Kadastro Genel Müdürlüğü Parsel Sorgulama Uygulaması'indan (https://parselsorgu.tkgm.gov.tr/\#ara/idari/129198 /23/10/1618947032088) ilgili parsellerin toplam alanı $2655 \mathrm{~m}^{2}$ bulunmuştur (Şekil 10). Yürürlükteki uygulama imar planına göre 23 nolu ada yapılaşma koşulları "Bitişik Nizam, 5 ve 6 kat", niteliği "Ticaret alanı" (Şekil 10-a) kapsamındadır.

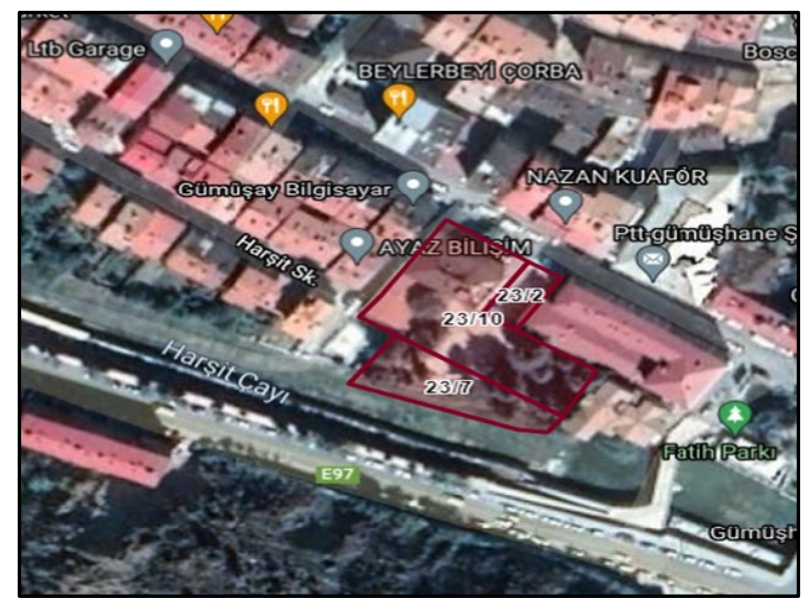

Şekil 10. 5 nolu plan düzenleme alanı uydu görünümü

"5 nolu plan değișikliğii" sonrası durum: Plan açıklama raporunda yapılan değişiklik (Şekil 10-b) için "23 nolu ada, 2-7-10 nolu parseller Millet Bahçesi, Ticaret + park + yol olarak yeniden planlanmış ve plan değiş̧ikliği sonucu gerekli

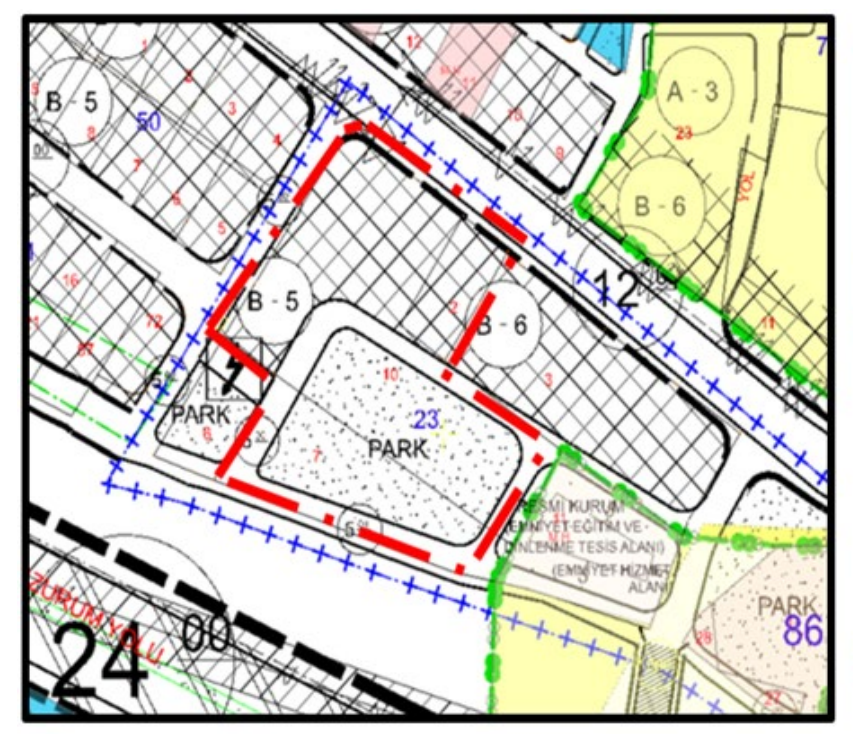

(a) olan yeşil alan 272 ada 1 parselden temin edilmiştir” denilmektedir.

"5 nolu plan değisikliği" icin inceleme bulguları: Plan açıklama raporunda yapılan plan değişikliğinin "mülkiyet deseni ve arazi kullanım kararları incelenerek Mekânsal Planlar Yapım Yönetmeliğine, Planlı Alanlar İmar Yönetmeliğine uygun bir biçimde" yapıldığ belirtilmekte ancak değişiklik gerekçesinden söz edilmemektedir. Şekil 11-b incelendiğinde söz konusu raporda önemli eksikliklerin olduğu tespit edilmiştir. Örneğin, adanın batı tarafında " $B-5$ olan yapılaşma koşulu, B-6 yapılmış" ve plan değişikliği sonucu "gerekli olan yeşil alanın 272 ada 1 parselden temin edildiğ i" belirtilmektedir. Ancak ne plan değişikliği sonrası durumda (Şekil 11-b) ne de parsel sorgu da, aynı mahalle içinde böyle bir parsele rastlanmamıştır. Millet bahçesi olarak düzenlendiği belirtilen kısım da görülmemektedir. Ayrıca düzenleme sahasındaki park alanının kuzey ve doğusunda "iptal edilen iki adet yoldan, parkın yaklaşık 1/3 alanının ticaret alanına dönüş̧ürrülmesinden" ve bunların "sayısal değerlerinden" de hiç bahsedilmemektedir. Gerek adanın batısındaki " $\boldsymbol{B}$ 5 olan yapılaşma koşulunun B-6'ya” gerekse "park alanından dönüşı̈̈rülen ticaret alanı" ile arazi sahiplerine çok önemli kazanımlar sağlanmıştır. Burada açıklanan inceleme bulgularına göre bu plan değişikliğinde herhangi bir "kamu yararı" veya "zorunluluk" tespit edilemediği gibi "park alanının kısmen ticaret alanına dönüsstürülmesi" ile önemli bir "kamu zararından" da söz edilebilir.

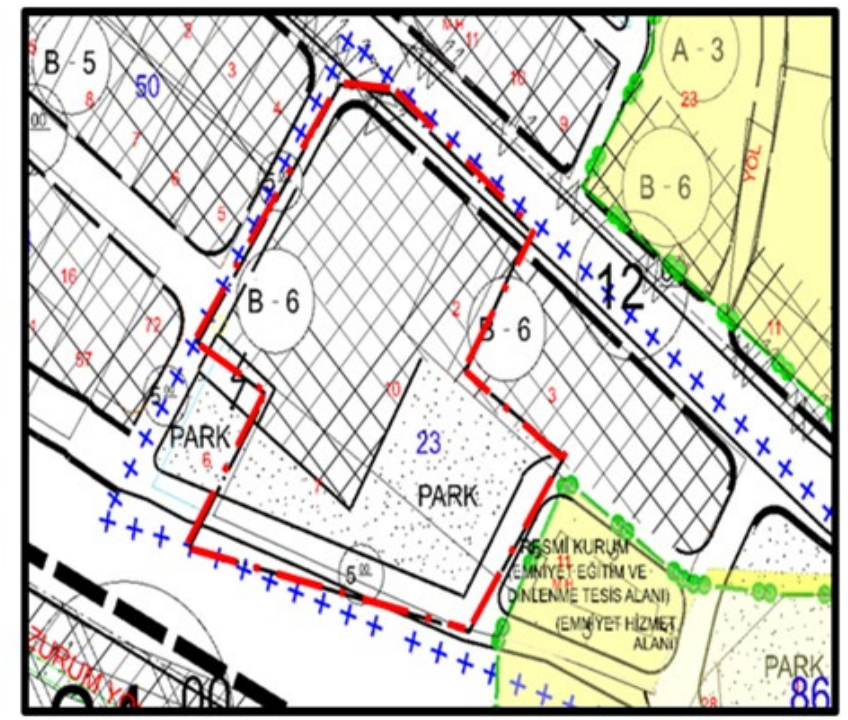

(b)

Şekil 11. 5 nolu plan düzenleme alanı plan değişikliği öncesi (a) ve sonrası durum (b) 


\section{Sonuçlar ve öneriler}

Uygulama imar planları ile; şehrin sahip olduğu imkânlar bilimsel verilerle analiz edilerek, kentte yaşayanlar için, mekânsal anlamda en uygun çözümler yasal mevzuat ve plan hiyerarşisi çerçevesinde üretilir. Ancak her zaman en uygun çözümün üretilmesi mümkün olmayabilir. $\mathrm{Bu}$ durum çoğunlukla planlar uygulanmaya başlandığında fark edilir ve sorunun çözümü için plan değişiklikleri yapılmaktadır. Ancak bu değişikliklerin yasal mevzuata uygun olması, kamu yararının gözetilmesi ve arazi sahiplerine sağlanan "emsal artışı ve ticaret alanina dönüştürme" aracına indirgenmemesi gerekir. Çünkü plan değişiklik süreçleri 1985 'te çıkarılan 3194 sayılı imar kanunu ile kolaylaşmış ve yerel idarelere çok geniş yetkiler verilmiştir. Seçimle işbaşına gelen yerel idarelere bu kadar geniş yetkilerin verilmesi, "zorunlu haller" ve "kamu yararının gözetilmesi” koşuluyla yapılabilen plan değişikliklerini, sıklıkla başvurulan bir düzenleme arac1 haline getirmiştir. Böylece plan uygulamalarında yapılan parsel ölçeğindeki plan değişiklikleriyle bütüncül yaklaşımdan git gide uzaklaşılmıştır. Her ne kadar 2020'de 3194 sayılı imar kanununa eklenen "Ek Madde 8" ile parsel bazında plan değişikliklerinin yapılamayacağı, ada bazlı değişikliklerde ihtiyaç duyulan sosyal teknik altyapı alanlarının adanın merkezine $500 \mathrm{~m}$ yarıçaplı bir alandan karşılanacağı, oluşacak değer artışının "değer artış payı olarak kamuya aktarılacağ ”" hükmü getirilse de çalışmanın 4. bölümünde incelediğimiz örneklerde de görüldüğü üzere, "parsel bazlı" plan değişikliği uygulamaları aynı hızla devam etmektedir. Plan değişikliği ölçütlerine uyulup uyulmadığı konusundaki sorumluluk Belediye Meclisi ve İmar Komisyonu üyelerine ait olmasına rağmen, seçmenlerine karş1 hissedilen sorumluluklar ve komisyonlardaki uzman sayısının yeterli olmaması, ölçütlere uygunluk denetimini zaafa uğratmaktadır.

Çalışmada seçilen plan değişikliği örneklerinin belirlenen yasal ölçütlere göre incelenmesi sonucunda aşağıdaki sonuçlara ulaşılmıştır:

1) Çalışmada seçilen plan değişikliği örneklerinde; 2020 yılı sonrasına ait olmasina rağmen "zorunlu" bir gerekçeye dayanmayan emsal artışl, kat artışl, konut veya park alanindan ticari alana dönüştürme gibi arazi sahiplerine önemli kazanımlar sağlandığ gözlemlenmiştir.

2) Kat yüksekliği artışlarında yolun her iki tarafinda yapılacak binalar arasında olması gereken asgari " $K$ " mesafesinin bazı durumlar için sağlanamadığını, benzer şekilde komşu adalarda yapılacak kat artışları için ise hiç dikkate alınmadığı tespit edilmiştir.

3) Hala "parsel bazlı" plan değişikliklerinin yapılabildiği, ihtiyaç duyulan "teknik ve sosyal altyapı ihtiyacı" nın karşılanmadığı, bulgularda ayrıntılarıyla gösterilmiştir.

4) "Ada bazlı plan değişikliklerinde oluşacak değer artışının kamuya aktarılması" konusu henüz yeni bir durum olduğu için sonraki çalışmalarda incelenebilir. Seçilen örnekler 2020 yılı sonrasına ait olmasına rağmen bu durumdan hiç söz edilmemektedir.

5) İmar komisyonunda planlama-imar disiplinleriyle ilişkili meslek grubuna mensup olanların sayısı oldukça az olduğu için plan değişikliği ölçütlerine uyulup uyulmadığı tam olarak belirlenememektedir. Marmara bölgesi imar komisyonu üyelerinin mesleki profilleri ile ilgili bir çalışmada üyeler arasında "mühendis" olanların oranı \%24.8 olarak bulunmuştur (Oktay, 2013). Plan değişikliklerinde "plan değişikliği ölçütlerine uyulup uyulmadığı" konusundaki sorumluluk Belediye Meclisi ve İmar Komisyonu üyelerine ait olmasına rağmen, seçmenlerine karşı hissedilen sorumluluklar "plan değişiklik ölçütleri" ne uygunluk denetimini zaafa uğratmaktadır. Çalışmada incelenen örneklerdeki bulgular, "plan değişikliği ölçütleri" ne çoğunlukla uyulmadığını açıkça gösterir niteliktedir.

6) İncelenen plan değişikliklerinden birisi hariç tamaminda "kamu yararı" veya "zorunluluk" tespit edilememiştir.

$\mathrm{Bu}$ sonuçlar dikkate alındığında ülkemizde plan değişikliklerinde "kamu yararı" ndan çok "bireysel yararlar" in daha ön planda tutulduğu söylenebilir. Bunun önlenebilmesi konusundaki öneriler şu şekilde sıralanabilir:

1) Plan değişikliklerini inceleyen Belediye Meclisi imar komisyonu, planlama ve imar konularında mesleki yeterliliğe sahip üyelerden oluşturulmalıdır. Bunun için Belediye Meclisi aday listelerinin oluşturulma aşamasında söz konusu yeterliliklere sahip kişilere yer verilmesine özen gösterilmelidir.

2) Mekânsal Planlar Yapım Yönetmeliği'nin 26/1 maddesinde "İmar planı değişikliği; plan ana kararlarını, sürekliliğini, bütünlügünü, sosyal ve teknik altyap dengesini bozmayacak nitelikte, kamu yararı amaçl, teknik ve nesnel gerekçelere dayanılarak yapılır" denmektedir. Çoğunlukla "soyut-nesnel" olan bu kriterlere uygunluğun belirlenebilmesi, plan değişikliğini talep eden/yarar sağlayacak 
kişiler veya seçmen baskısı altındaki imar komisyonu üyelerinden beklenmemelidir. Plan değişikliklerinde söz konusu kriterlere uymama durumu daha çok özel mülkiyete ait arazilerdeki plan değişiklerinde sağlanan büyük imar kazanımları ile ilgilidir. $\mathrm{Bu}$ nedenle imar komisyonu kamu kurumları dışında hazırlanan her plan değişikliği için Üniversite Şehir Planlama veya Harita Mühendisliği bölümlerindeki ilgili uzmanlardan, "Plan Değişiklik Kriterlerine Uygunluk Raporu" istemeli ve bu rapora göre kararını vermelidir.

3) İmar planları hazırlanırken yapılan ön çalışmalardaki veriler titizlikle toplanarak incelenmeli, süreç şeffaflık içerisinde yürütülmeli ve kentin yerel-fiziki- sosyal yapısına uygun imar planları yapılmalıdır. Bu durum plan değişiklik taleplerini büyük oranda azaltacaktır.

4) Şehirlerimizin yaşanabilir bir mekânsal dokuya sahip olması o kentte yaşayanları mutlu kılar. $\mathrm{Bu}$ sorumluluk sadece yerel idareciler ve imar komisyonu üyelerine yüklenemez. Bunun için ortak ve sosyal bir bilincin oluşmasına ihtiyaç vardır. Bu olgu ve bilinçlenme düzeyi, yerel idarelerin bu konularda yapacağı çeşitli etkinlik ve sosyal medya yayınları ile oluşturulabilir.

\section{Kaynaklar}

Alfasi, N. (2006). Planning policy? Between long-term planning and zoning amendments in the Israeli planning system. Environment and Planning A: Economy and Space. 38(3), 553-568. https://doi.org/10.1068/a37335

Altın, Y. (2006). İstanbul metropoliten alanında imar planı değişiklikleri ile ilgili bir analiz. Yüksek Lisans Tezi, İstanbul Teknik Üniversitesi Fen Bilimleri Enstitüsü, İstanbul.

Bademli, R. S. (1998). Modifying urban physical development plans in metropoliten cities: Case of Ankara, Yüksek Lisans Tezi, ODTÜ, Ankara.

Bakır, N. Y. Doğan, U. Güngür, M. K. and Bostancı, B. (2018). Planned development versus unplanned change: The effects on urban planning in Turkey, Land Use Policy, 77, 310-321. https://doi.org/10.1016/j.landusepol.2018.05.03 6

Çevre ve Şehircilik Bakanlığı, (2021). Türkiye geneli plan istatistikleri, Erişim adresi https://eplan.gov.tr/KesinlesenPlanListesi

Çiçek, K. (2016). Imar plan değişikliklerinin usul ve esaslarl. Yüksek Lisans Tezi. İstanbul Ticaret Üniversitesi Sosyal Bilimler Enstitüsü. İstanbul.
Çolak, N. İ. ve Öngören, G. (2014). Imar planlart, imar uygulamalarl ve iptal davalarl (2. Bask1). İstanbul: Öngören Hukuk Yayınlar.

Demir, A. M. (2009). İmar planı değişikliklerinin değerlendirilmesi Zeytinburnu örneği. Yüksek Lisans Tezi. İstanbul Teknik Üniversitesi. İstanbul.

Eminagaoglu, Z. (2018). Examination of zoning plan modifications and effects on whole plan: Artvin sample, International Journal of Scientific and Technological Research, 4(9), 69-80. ISSN 2422-8702 (Online).

Ersoy, M. (1997), İmar planı değişiklikleri ve yarg1 denetimi, ODTÜ Mimarlık Fakültesi Dergisi, (17:1-2), 53-73.

İnceyol, Y. (2019). İmar planı tadilatlarında arazi sahiplerinin kazanımları ve mekânsal dokuda oluşturduğu etkilerin incelenmesi. Mehmetoğlu, T. ve Şahin, E. İ. (Ed), 1. Uluslararası Malatya Uygulamall Bilimler Kongresi (ISPEC) Cilt 2 (pp. 120-128), Malatya.

Karaman, S. (2012). Imar planı değişiklikleri konusunda Muğla/Yalıkavak örneği üzerine bir inceleme, Yüksek Lisans Tezi, Muğla Sitkı Koçman Üniversitesi Sosyal Bilimler Enstitüsü, Muğla.

Keleş, R. ve Mengi, A. (2014). İmar Hukukuna Giriş (2. Baskı). Ankara: İmge Yayınevi.

Kılınç, N. ve Türk, Ş. Ş. (2018). İmar planı değişikliği talebi-arzı ve sosyo-ekonomik değişkenler arasındaki ilişki: İstanbul örneği, Kubat, A. S. vd. (Ed), Türkiye kentsel morfoloji araştırma ă̆g II. kentsel morfoloji sempozyumu (pp. 853-870) İTÜ Mimarlık Fakültesi, Taşkışla, İstanbul.

Namlı, B.S. (2017). Imar planlarının hazırlanmast ve uygulanması, Yüksek Lisans Tezi, Başkent Üniversitesi Sosyal Bilimler Enstitüsü Hukuk Anabilim Dalı Kamu Hukuku Yüksek Lisans Program1, Ankara.

Oktay, T. (2013). Kuramdan uygulamaya yerel yönetimler ve kentsel politikalar, belediye meclisi imar komisyonlarının üye profili: Marmara Bölgesi Örneği (1. Bask1). Ankara: Pegem Akademi Yayınları.

Öngören, G. (2020). Yarg1 kararları 1şı̆̆ında imar hukuku, Öngören Hukuk Yayınları, Yayın No: 8, İstanbul.

Sesli, F. A. ve Karadavut, E. (2009). İmar planı değişikliklerinin plan bütünlüğüne etkilerinin incelenmesi, TMMOB Coğrafi Bilgi Sistemleri Kongresi (02-06 Kasım), İzmir.

Suher, H. (1985). Plan, planlama-düzenleme kavramları, planlamanın fonksiyonları, 
planlamanın meşguliyet alanı. Şehircilik, İTÜ ŞBP. S: 6-10, 18-19, 24-25.

Tekeli, İ. (1988). Mülkiyet kurumu, kamu yararı kavramı ve imar planları üzerine. Planlama Dergisi, TMMOB Şehir Plancıları Odası Yayını. s: 6-16.

TMMOB Şehir Plancıları Odası, 10. Dönem Çalışma Raporu (2018-2020), s: 34, Erişim adresi https://www.spo.org.tr/resimler/ekler/1d760dda 9458e58_ek.pdf?tipi $=2 \&$ turu $=X \&$ sube $=3$

Türkiye İstatistik Kurumu (TÜİK), (2021). Adrese Dayalı Nüfus Kayıt Sistemi Sonuçları, 2020, Erişim $\quad$ adresi https://data.tuik.gov.tr/Bulten/Index?p=AdreseDayal\%C4\%B1-N\%C3\%BCfus-Kay\%C4\%B1tSistemi-Sonu $\%$ C3\%A7lar\%C4\%B1-2020$37210 \&$ dil $=1$

Tiyek, Y. ve Ulusoy, Y. (2020). İmar planlarının yapılması, değiştirilmesi ve ortadan kaldırılması usulleri. Pamukkale Üniversitesi İsletme Araştırmaları Dergisi, PIAR'2020 / 7(2), 262287. https://doi.org/10.47097/piar.823555

Turgut, K. (2012). Yerel ve kentsel politikalar: Belediyelerde imar planı değişikliği uygulamalart ve denetimi (2. Bask1). Konya: Çizgi Kitabevi Yayınları.

Ünlü, T. (2007). Mersin'in mekansal biçimlenme süreci ve planlama deneyimleri, Gazi Üniversitesi Mühendislik Mimarlık Fakültesi Dergisi, 22(3), 425-436.

Ünlü, T. (2009). Mekansal planlamanın kentin biçimlenmesine etkisi: Mersin örneği, Planlama Dergisi, 3 (4), 27-42.

Ünlü, T. (2018). Mekânın biçimlendirilmesi ve kentsel morfoloji, Kubat, A. S. vd. (Ed), Türkiye Kentsel Morfoloji Araştırma A $\breve{g}_{l}$ II. Kentsel Morfoloji Sempozyuтu (pp.59-70). İstanbul: İTÜ Mimarlık Fakültesi Taşkışla.

Yavuz, U. ve Sertyeşilışık, B. (2019). Mekânsal alanlarda plan değişikliklerinin gayrimenkul üretim/arz eğilimlerine etkileri, International Journal of Political Science \& Urban Studies, $7(2)$, 543-567. https://doi.org/10.14782/ipsus.623466

Yildı, F. (2014). Imar bilgisi Planlama-UygulamaMevzuat (9. Baskı). Ankara: Nobel Yayınevi. 